\title{
1
}

\section{Sobre música}

\subsection{A MÚSICA E SUA INFLUÊNCIA}

Qualquer consideração acerca de tema tão amplo como a música requer que nos situemos inicialmente em relação ao objeto que será estudado. Nesse particular, é possível constatar que as tentativas de se definir música têm despertado controvérsia, críticas e objeções que, no conjunto, acabam por propiciar um panorama desta manifestação humana.

O musicólogo francês Roland de Candé, afirma que a música "nunca é definida de forma conveniente: é dificil observarmos uma ação em que nos achamos envolvidos" (2001, p. 10), e faz uma breve incursão sobre algumas definições propostas. Reporta que para o filósofo e escritor francês J.J. Rousseau (1712-1778), a música seria "a arte de reunir os sons de maneira agradável ao ouvido" (2001, p. 10), mas contrapõe a essa definição a música ritual, a música dramática e a música militar, que não teriam aquela finalidade. Indaga ainda se uma mesma música pode ser agradável aos ouvidos de 
todos os homens, independentemente de etnia ou cultura. Outra definição citada é a do também conhecido filósofo e lexicólogo francês Littré (1801-1881), para quem a música constitui "ciência ou emprego dos sons ditos racionais, isto é, que entram numa hierarquia chamada escala" (2001, p. 10). Essa definição também traria dificuldades, como exemplifica Candé, ao referir-se a crianças tamborilando música em um piano ao som de uma escala, as expressões sonoras contemporâneas de Pendereki (1933___ ), Ligeti (19232006) ou Xenakis (1922-2001) e até dos percussionistas africanos. Na opinião de Candé, uma das melhores definições de música seria a do engenheiro e filósofo Abraham Moles (1920-1992): "uma reunião de sons que deve ser percebida como não sendo o resultado do acaso" (2001, p. 10). Mesmo para esta definição aponta fraquezas ao lembrar a repetição automática de sons escolhidos de forma arbitrária ou até a fala ${ }^{42}$.

Para Candé, as definições de música, em sua maioria, não a consideram um sistema de comunicação que, no entender do musicólogo, seria não referencial, já que "o sentido da música lhe é imanente" (2001, p. 10). Apresenta, então, as seguintes considerações ${ }^{43}$ :

"Constatamos que tudo o que nos parece música é:

- um complexo sonoro, sem significação nem referência exterior (a linguagem não é música, mesmo nas línguas 'em tons');

- o fruto de uma atividade projetiva, mais ou menos consciente: um "artefato" (não há música 'natural', nem puramente aleatória);

- uma organização comunicável: ela associa um organizador-emissor (músico ativo, compositor-intérprete) a um receptor (ouvinte) por um conjunto de convenções que permite uma interpretação comum do 'sentido' da organização sonora. No minimo, a atividade projetiva será percebida como tal, porque, se o agregado de sons parece

42 CANDÉ, Roland de. História Universal da Música. 2a ed. São Paulo: Martins Fontes, 2001, p. 10.

43 CANDÉ, Roland de. História Universal da Música. $2^{a}$ ed. São Paulo: Martins Fontes, 2001, p. 10-14. 
natural, só pode ser qualificada de música por metáfora (música de um riacho).

Em suma, a música parece ter sido, até hoje, a ação de agregar sons em função de um projeto comunicável, sem referência a uma realidade exterior. Ou então: a música é a comunicação de um agregado de sons organizados, agregado não significante, mas coletivamente interpretável" (Candé, 2001, p. 13-14).

Os esforços para se definir música, refletidos em tantas propostas, nos remetem ao musicólogo e semiólogo musical Jean-Jacques Nattiez, que, referindo-se ao seu mestre Jean Molino, assim se pronunciou $^{44}$ :

"Não há limite ao número ou gênero de variáveis que podem intervir em uma definição do musical. Para Molino, adaptando expressão de Marcel Mauss, música é um 'fato social total' ['fait social total'], cuja definição varia de acordo com a era e a cultura" (Nattiez, 1990, p. 42).

O pianista e regente Daniel Barenboim, acredita ser impossível falar sobre música e que as muitas definições existentes contêm uma descrição de uma reação subjetiva. Para ele, a melhor definição é a do compositor e pianista italiano Ferrucio Busoni (1866-1924), que sustenta que música é ar sonoro, pois descreveria simultaneamente tudo e nada ${ }^{45}$.

O músico, compositor e professor de literatura, José Miguel Wisnik, também oferece sua contribuição ao debate ao afirmar que ${ }^{46}$ :

"A música, em sua história, é uma longa conversa entre o 'som' (enquanto recorrência periódica, produção de constância) e o 'ruido' (enquanto perturbação relativa da es-

44 NATTIEZ, Jean-Jacques. Music and Discourse. Toward a Semiology of Music. Princeton, New Jersey: Princeton University Press, 1990, p. 42.

45 BARENBOIM, Daniel. A Música Desperta o Tempo. São Paulo: Martins Fontes, 2009, p. 11.

46 WISNIK, José Miguel. O Som e o Sentido - Uma Outra História das Músicas. $2^{a}$ ed. São Paulo: Companhia das Letras, 2006, p. 30. 
tabilidade, superposição de pulsos complexos, irracionais, defasados). Som e ruído não se opõem absolutamente na natureza: trata-se de um 'continuum', uma passagem gradativa que as culturas irão administrar, definindo no interior de cada uma qual a margem de separação entre as duas categorias (a música contemporânea é talvez aquela em que se tornou mais frágil e indecidivel o limiar dessa distinção)" (Wisnik, 2006, p. 30, grifo nosso).

O musicólogo tcheco, Bruno Nettl, em um artigo disponível na publicação eletrônica "Oxford Grove Music Online", defende que apresentar a palavra música em um dicionário de música implicaria uma definição autoritária ou envolveria um entendimento muito abrangente do seu conceito. Nesse último caso, seria necessária uma análise de muitos aspectos (tais como o linguístico, biológico, psicológico, filosófico, histórico, antropológico, teológico, jurídico e médico), juntamente com o musical em sentido amplo. Considerando a variedade da música no mundo, a diversidade cultural e as concepções de música, é possível, segundo Nettl, pesquisar as diferentes visões sobre o tema, em diversas fontes, como dicionários de uso geral, dicionários de música (alguns nem mesmo possuem o verbete), enciclopédias (que, não raro, têm uma preocupação com o contexto cultural), obras de autoridades europeias do passado (especialmente de teóricos e compositores dos séculos XVIII ao XX) ou trabalhos de musicólogos. Afirma, outrossim, que em nenhuma cultura existe uma unanimidade quanto às questões fundamentais acerca da natureza da música e que a definição de música, de uma forma universal e intercultural, esbarra na linguagem e na visão cultural dos seus autores. Não obstante, reconhece que há concordância quanto a música constituir um fenômeno cultural universal, especialmente o canto, já que em todas as sociedades identificam-se expressões vocais que se distinguem da fala comum ${ }^{47}$.

Apesar do desafio de se definir música de forma absoluta, de desvendar por inteiro seu 'modus operandi' e de explicar em detalhe

47 NETTL, Bruno. Music. Grove Music Online, itens I.1 a 5; III. 1 a 5, 7-8. Disponível em: <www.oxfordmusiconline.com:80/subscriber/article/grove/music/40476>. Acesso em: 29/08/2009. 
sua função social, Candé, juntamente com muitos outros, constata que por vezes pode nos comover intensamente ${ }^{48}$, qualidade esta do som que vem sendo explorada por todas as culturas ${ }^{49}$.

Assim, muito embora a música seja associada a uma gama de emoções e humores, a cultura ocidental de maneira geral, e quase sempre, a considera um fenômeno positivo ligado, juntamente com as pessoas que em torno dela gravitam, ao belo e ao bem; apenas ocasionalmente é vista como nefasta ou tendo um papel na expressão da tristeza $^{50}$ como sugere neste último caso o trecho do romance " $A$ Náusea", do filósofo e escritor, Jean-Paul Sartre (1905-1980), também um pianista ${ }^{51}$ :

"Agora há essa melodia de saxofone. E sinto vergonha. Acaba de nascer um sofrimentozinho glorioso, um sofrimentomodelo. Quatro notas de saxofone. Vão e vêm, parecem dizer: 'É preciso fazer como nós, sofrer em compasso"' (Sartre, 2006, p. 215, grifo nosso).

Para Wisnik, o som é um objeto subjetivo, que não pode ser tocado de forma direta, mas que toca o ser humano de forma muito precisa, servindo à criação de metafísicas. Afirma que ${ }^{52}$ : "suas propriedades ditas dinamogênicas tornam-se, assim, demoníacas (o seu poder, invasivo e às vezes incontrolável, é envolvente, apaixonante e aterrorizante)" (2006, p. 28, grifo nosso).

Mario de Andrade (1893-1945), precursor dos estudos no Brasil sobre música e seu uso na saúde, já considerava que os efeitos psíqui-

48 CANDÉ, Roland de. História Universal da Música. $2^{\text {a }}$ ed. São Paulo: Martins Fontes, 2001, p. 14-17.

49 JOHNSON, Bruce; CLOONAN, Martin. Dark Side of the Tune: Popular Music and Violence. Hampshire: Ashgate Publishing, 2008, p. 14.

50 NETTL, Bruno. Music. Grove Music Online, item II.1. Disponível em: $<$ www.oxfordmusiconline.com:80/subscriber/article/grove/music/ 40476>. Acesso em: 29/08/2009.

51 SARTRE, Jean-Paul. A Náusea. $1^{\mathrm{a}}$ ed. Rio de Janeiro: Nova Fronteira, 2006, p. 215.

52 WISNIK, José Miguel. O Som e o Sentido - Uma Outra História das Músicas. $2^{\text {a }}$ ed. São Paulo: Companhia das Letras, 2006, p. 28. 
cos e fisiológicos da música estavam suficientemente comprovados pela experiência individual das pessoas, pela tradição e pela ciência, mas indagava de onde viria seu extraordinário poder de atuação sobre os indivíduos e sobre as massas. Suas conclusões apontam para dois aspectos fundamentais ${ }^{53}$. O primeiro deles consiste na força do ritmo:

"A consequência fisiológica do ritmo é coletivizar o ser e aguçar-lhe as faculdades. A sua consequência patológica é a bebedice, o depauperamento, a extirpação mesmo das faculdades da consciência e da razão, provocando assim, ora estado de sonolência, ora de encantação, ora de exaltação dionísica, bem próprios para aceitar qualquer absurdo" (Andrade, 1980, p. 16, grifo nosso).

O segundo aspecto, que demonstraria o poder de atuação biológico da música, consistiria na indestinação intelectual do som, i.e., a música "não contém imagens que sejam representações inteligíveis" (Andrade, 1980, p. 19), contém uma significação em si mesmo. Conforme expõe Edward W. Said (1935-2003)54: "Primeiro: a música como forma artística não é como a língua; as notas não significam uma coisa fixa, como as palavras 'gato ou cavalo"' (Said, In: Said; Barenboim, 2003, p. 181). Mário de Andrade, por sua vez, aponta que a música não nos prende a determinadas questões ou imagens, o que seria produto da sensibilidade de cada $u^{55}$. E, ao referir-se ao poder sugestivo do som, declara que "apesar de sua ininteligibilidade essencial, se torna símbolo e evocação das mais altas ideias e dos mais delicados sentimentos" (Andrade, 1980, p. 26).

Assim, para Mario de Andrade:

"Na música, como os sons não são representação de coisa alguma, e as melodias são puras imagens sonoras de sen-

53 ANDRADE, Mario de. Terapêutica Musical. In: Namoros Com a Medicina. $4^{a}$ ed. São Paulo: Martins Ed., 1980, p. 13-59.

SAID, Edward W.. Barenboim e o Tabu Wagner. In: BARENBOIM, Daniel; SAID, Edward W.. Paralelos e Paradoxos. Reflexões sobre música e sociedade. São Paulo: Companhia das Letras, 2003, p. 177-188. 
tido próprio, o ritmo se apresenta puro, indisfarçado, não desviado, contendo a sua significação em si mesmo. Daí poder ele manifestar toda a sua violenta força dinamogênica sobre o indivíduo e sobre a multidão" (Andrade, 1980, p.14, grifo nosso).

A saudosa musicista, pesquisadora e educadora, Maria de Lourdes Sekeff Zamprogna (1934-2008), observa que a qualidade polissêmica $^{56}$ da música - com seus sentidos plurais e simbólicos - alcança múltiplos aspectos da dimensão humana, tais como o físico, mental, espiritual, social e emocional. Ensina que a música não seria apenas uma combinação de sons, ruído e silêncio, com fins estéticos, mas também recurso de 'expressão' (de sentimentos, ideias, valores, cultura, ideologia), de 'comunicação' (interna e externa), de 'gratificação' (psíquica, emocional, artística), de 'mobilização' (física, motora, afetiva, intelectual) e de 'autorrealização' ${ }^{57}$. E, além de servir de recurso educacional, a ciência contemporânea reconhece a atuação psicofisiológica da música e sua importância no campo da saúde, agindo por meio de elementos como o ritmo, melodia e harmonia que "tem sempre o poder de nos alcançar, e contra isso somos relativamente indefesos" (Sekeff, 2007, p. 24).

Os efeitos psicofisiológicos da música sobre o ser humano constituem objeto de estudo para diversas áreas da saúde. A neurociência, com ênfase a partir dos anos 1980, tem se ocupado de investigar as relações entre a música e o cérebro; e a obra de Oliver Sacks, em especial "Alucinações Musicais", traz interessantes relatos acerca desse

56 Polissemia: trata-se de termo que diz respeito aos diversos sentidos de uma palavra, e bastante utilizado para se referir à música. "Cada lexia pode possuir significados variáveis ou invariáveis, segundo o seu sentido geral, conforme a visão do mundo de uma classe social pertencente a uma determinada formação social e num momento histórico, dado e consoante o vocabulário utilizado pelos indivíduos componentes dos diversos grupos socioprofissionais de uma formação social concreta." Cf. CONTIER, Arnaldo D. Imprensa e Ideologia em São Paulo (1822-1842). Petrópolis: Vozes; Campinas: Universidade Estadual de Campinas, 1979, p. 21.

57 SEKEFF, Maria de Lourdes. Da Música, Seus Usos e Recursos. $2^{\mathrm{a}}$ ed. rev. e ampl. São Paulo: Ed. UNESP, 2007, p. 14, 18-9, 24, 32-35. 
novo campo de pesquisa. Para Sacks, ouvir música envolve não só um processo auditivo e emocional, mas também motor, e lembra uma frase de Nietzsche (1844-1900): "Ouvimos música com nossos músculos" (2007, p.11). Nota que o acompanhamento do ritmo é, muitas vezes, involuntário e inconsciente e que a postura corporal e o rosto retratam os sentimentos e pensamentos por ele causados. O neurocientista e psicólogo Daniel J. Levitin, da McGill University, no Canadá, atesta que em todas as culturas o movimento é considerado parte integrante do processo de fazer e escutar música ${ }^{58}$. Sacks faz referência às conclusões do neurocientista do 'Neuroscience Institute', na Califórnia, Aniruddh D. Patel, no sentido de que "em toda cultura existe alguma forma de música com um ritmo regular, um pulso periódico que permite a coordenação temporal entre os executantes e evoca respostas sincronizadas dos ouvintes" (2007, p. 233). Desenha também um interessante paralelo entre as oscilações neuronais que ligam partes no cérebro e no sistema nervoso e o ritmo que "liga os sistemas nervosos dos indivíduos de uma comunidade humana" (2007, p. 240). Tece ainda as seguintes considerações ${ }^{59}$ :

"O poder quase irresistível do ritmo evidencia-se em muitos outros contextos: nas marchas, serve para impulsionar e coordenar o movimento e para estimular uma excitação coletiva e talvez marcial. Isso ocorre não só com músicas militares e tambores de guerra, mas também com o lento e solene ritmo de uma marcha fúnebre. Também vemos isso em todo tipo de canção de trabalho - músicas rítmicas que provavelmente surgiram nos primórdios da agricultura, quando arar o solo, capinar e malhar grãos requeriam os esforços combinados e sincronizados de um grupo de pessoas. O ritmo e seu arrasto do movimento (e frequentemente da emoção), seu poder de mover e comover as pessoas, pode muito bem ter tido uma função cultural e econômica crucial na evolução humana, unindo as pessoas, gerando um sen-

58 LEVITIN, Daniel J. This is Your Brain on Music: the science of a human obsession. New York: Penguin Group, 2006, p. 55.

59 SACKS, Oliver. Alucinações Musicais. Relatos sobre a Música e o Cérebro. São Paulo: Companhia das Letras, 2007, p. 11, 227-240. 
timento de coletividade e comunidade" (Sacks, 2007, p. 239, grifo nosso).

Nesse sentido, o professor de História Marcos Napolitano, da Universidade de São Paulo (USP), assinala que a música tem servido de elemento catalisador de reuniões coletivas e lembra de uma função social básica, que constitui ainda hoje uma das formas de experiência musical: a dança ${ }^{60}$.

Sacks faz ainda uma revelação importante ao constatar que muito do que ocorre durante a escuta musical também acontece quando a música é 'tocada na mente' (2007, p.11)

"O mais notável foi sua descoberta [Chen, Zatorre e Penhune, em Montreal] de que ouvir música ou imaginá-la, mesmo sem nenhum movimento flagrante ou sem acompanhar o ritmo, também ativa o córtex motor e sistemas motores subcorticais. Portanto, imaginar música ou ritmo pode ser neuralmente tão potente quanto ouvi-los de verdade" (Sacks, 2007, p. 234, grifo nosso).

Rolando Benezon, médico, psicanalista e músico argentino, com uma importante obra e ensinamentos na Musicoterapia, sintetiza as diferentes respostas que o som pode produzir no ser humano, as quais não surgem de forma autônoma, mas se relacionam: resposta matriz (andar, correr, marchar, dançar); resposta emotiva (rir ou chorar); resposta orgânica (rubor, secreções, descontração); resposta de comunicação (por meio da expressão sonora ou até não verbal); ou uma resposta de conduta (como o condicionamento e aprendizagem) ${ }^{62}$. Tais reações, conforme nos ensina Martin Cloonan, professor de música popular e política na Escócia, têm permitido que cada vez mais a música e outras sonoridades sejam usadas para modificar o compor-

60 NAPOLITANO, Marcos. História \& Música. Belo Horizonte: Autêntica Ed., 2005, p. 12-15.

61 SACKS, Oliver. Alucinações Musicais. Relatos sobre a Música e o Cérebro. São Paulo: Companhia das Letras, 2007, p. 11, 42, 234.

62 BENENZON, Rolando. Teoria da Musicoterapia. Contribuição ao conhecimento do contexto não verbal. $2^{\mathrm{a}}$ ed. São Paulo: Summus Editorial, 1988, p. 23. 
tamento e regular a ocupação de locais públicos, transformando-os em espaços privados ou mesmo desestabilizando as relações entre tais espaços ${ }^{63}$.

Tais considerações acerca da música visam tão apenas ilustrar os espinhos que protegem essa produção humana, um tanto enigmática, de qualquer tentativa de aprisionamento, ainda que em uma definição. Por esse motivo, os termos música, som, sonoridade e ruído, por vezes, são usados de forma intercambiável. Apesar das dificuldades quanto a uma definição, a ciência moderna, com os recursos das novas tecnologias, começa a desvendar as manifestações psicofisiológicas da música até então observadas empiricamente. Malgrado os esforços para se definir música, Daniel Barenboim declara que ${ }^{64}$.

"O poder da música reside em sua capacidade de se comunicar com todos os aspectos do ser humano - o animal, o emocional, o intelectual e o espiritual. Com muita frequência, pensamos que as questões pessoais, sociais e políticas são independentes, sem influir umas nas outras. Pela música, aprendemos que essa é uma impossibilidade objetiva; simplesmente não existem elementos independentes. O pensamento lógico e as emoções intuitivas devem estar constantemente unidos. A música nos ensina, em resumo, que tudo está ligado" (Barenboim, 2009, p. 125, grifo nosso).

\subsection{MÚSICA E POLÍTICA}

Conforme ensina o compositor e professor canadense R. Murray Schafer, a associação do ruído e poder habita a mente humana, já

63 CLOONAN, Martin. Bad Vibrations. New Humanist, v. 124, Issue 2. March/April 2009. Disponível em: <http://newhumanist.org.uk/2014/bad-vibrations > Acesso em: 02/11/2009; e, JOHNSON, Bruce. Musical torture has pedigree of mythic proportions. National Times. Theage.com.au. 27 de outubro de 2009. Disponível em: <http://www.theage.com.au/opinion/society-and-culture/musical-torture-has-pedigree-of-mythic-proportions-20091027-hhb8.html>. Acesso em: 02/11/2009.

${ }_{64}$ BARENBOIM, Daniel. A Música Desperta o Tempo. São Paulo: Martins Fontes, 2009, p. 125. 
que no passado remoto os ruídos fortes provocavam medo e respeito, pois sugeriam a expressão do poder divino. Com o passar dos tempos, o poder intimidatório dos sons naturais, como o da chuva e dos trovões, migrou para os sons produzidos pelo homem, como os sinos e os órgãos das igrejas e, mais tarde, com a Revolução Industrial, para os sons do mundo profano. Ressalta que o ruído é meio de chamar a atenção e que, se fosse possível fazer máquinas sem ele, é provável que a industrialização não tivesse tido o mesmo sucesso. Afirma de forma drástica que: "se os canhões fossem silenciosos, nunca teriam sido utilizados na guerra" (2001, p. 115). Deu a esses sons a designação de Ruído Sagrado $^{65}$, diferenciando de outros ruídos que exigem regramentos para impor sua diminuição, citando especialmente "a turbulenta voz humana"66 (2001, p.113):

"A associação entre Ruido e poder nunca foi realmente desfeita na imaginação humana. Ele provém de Deus, para o sacerdote, para o industrial e, mais recentemente, para o radialista e o aviador. O que é importante perceber é que: ter o Ruído Sagrado não é, simplesmente, fazer o ruído mais forte; ao contrário, é uma questão de ter autoridade para fazê-lo sem censura.

Onde quer que o Ruído seja imune à intervenção humana, ali se encontrará um centro de poder" (Schafer, 2001, p. 114).

Essa concepção está presente na obra do aclamado artista plástico brasileiro, Cildo Meireles, especialmente nas instalações "Babel"

65 "Ruído sagrado: Qualquer som prodigioso (ruido) que seja livre da proscrição social. Originalmente, o Ruído sagrado refere-se a fenômenos naturais, como o trovão, erupções vulcânicas, tempestades etc., pois acreditava-se que representassem combates divinos ou a ira dos deuses para com o homem. Por analogia, a expressão pode ser estendida aos ruídos sociais que, pelo menos durante certos períodos, têm escapado à atenção dos legisladores da redução de ruido, como os sinos de igreja, o ruído industrial, a música 'pop' amplificada etc." Cf. SCHAFER, R. Murray. A Afinação do Mundo. São Paulo: Editora UNESP, 2001, p. 368.

66 SCHAFER, R. Murray. A Afinação do Mundo. São Paulo: Editora UNESP, 2001, p. 113-5. 
(2001) e "Marulho" (2007). A primeira consiste em uma torre de mais de dois metros de diâmetro e cinco metros de altura, feita da sobreposição de rádios, todos ligados. À medida que o visitante se aproxima, os sons, inicialmente confusos, passam a ser percebidos de forma 'clara e distinta'. A segunda consiste numa plataforma, semelhante a um píer, que se projeta sobre milhares de livros abertos em tons azulados que cobrem o chão, sugerindo o movimento do mar. Pode-se escutar o murmúrio das ondas, formado com a pronúncia da palavra ‘água' em 80 línguas diferentes por pessoas de diversas origens, gênero e idades. Dentre as propostas das obras, observa-se que ${ }^{67}$ :

"O destaque que, em detrimento de outras, uma emissão radiofônica ou uma língua transitoriamente possuem nesses trabalhos sugere, ademais, as desigualdades que presidem as trocas simbólicas, posto que quanto mais poder econômico e político possui uma unidade nacional (ou regional), maior sua capacidade de se fazer ouvir - exercendo, portanto, o seu 'direito de narrar' - ou de fazer sua língua ser entendida por aqueles que não a trazem como recurso comunicativo natural" (Anjos, In: Meireles, 2006, p. 42).

Bruce Johnson, professor de estudos culturais e música na Finlândia, na Escócia e na Austrália, ensina que a incerteza acerca da fonte sonora por si só estabelece uma relação de poder entre um emissor invisível e um receptor inquieto. O efeito da onipresença produz desconforto, que vai da simples ansiedade a crises de pânico. E a impossibilidade de se identificar de onde provém o som pode gerar a crença em manifestações de forças superiores ou em um poder transcendental como, no entender de Johnson, seriam Deus, o Estado, a Natureza ou o Pai ${ }^{68}$.

Essas questões provocam indagações acerca da relação entre música e política, que também constitui um campo igualmente tor-

67 MEIRELES, Cildo. Babel. (texto e curadoria Moacir dos Anjos). Rio de Janeiro: Artviva Ed., 2006; São Paulo. Catálogo da exposição realizada na Estação Pinacoteca do Estado de São Paulo de 08 a 26 de outubro de 2006, p. 11-52

68 JOHNSON, Bruce; CLOONAN, Martin. Dark Side of the Tune: Popular Music and Violence. Hampshire: Ashgate Publishing, 2008, p. 17. 
mentoso para os estudiosos. Wisnik nos apresenta um bom resumo dos principais focos desta problemática ${ }^{69}$ :

"Tradicionalmente, um dos nós da questão política na música esteve na separação, levada a efeito pelos grupos dominantes, entre a música "boa" e a música "má", entre a música considerada elevada e harmoniosa, por um lado, $e$ a música considerada degradante, nociva e 'ruidosa', por outro. Na verdade, isso se deve a que a própria ideia de 'harmonia', que é tão musical, aplique-se desde longa data à esfera social e política, para representar a imagem de uma sociedade cujas tensões e diferenças estejam compostas e resolvidas. Do ponto de vista dominante, a contestação e a diferença aparecem como "ruídos", como cacófatos sociais, como dissonâncias a serem recuperadas segundo um código ideológico do qual muitas vezes a música oficial figura como sendo a demonstração "natural" (Wisnik, In: Bosi, 2008, p. 115, grifo nosso).

Reconhece Wisnik ser muito difícil falar sobre as conexões entre a política e a música uma vez que, conforme visto na Seção 1.1, esta não exprime um conteúdo de forma direta. E, referindo-se à canção, que possui uma letra, aponta que o seu sentido estaria incorporado de forma sutil e inconsciente no seu ritmo, timbre, intensidade e nas tramas melódicas e harmônicas ou, como ilustrado por Chico Buarque em uma entrevista: “... Pra mim, a letra e a música são juntas. Prefiro ouvir com a música. Tenho a impressão que publicar uma letra é metade de meu trabalho. É um negócio a cores e exibido em preto e branco"70 (HOLLANDA, 1976 apud Fiúza, 2001,

69 WISNIK, José Miguel. Algumas Questões de Música e Política no Brasil. In: BOSI, Alfredo (org.). Cultura Brasileira, Temas e Situações. $4^{\mathrm{a}} \mathrm{ed}$. $7^{\mathrm{a}}$ reimpressão. São Paulo: Editora Ática, 2008, p. 115.

70 HOLLANDA, Chico B. de. "Entrevista". In: O Som do Pasquim: grandes entrevistas com os astros da música popular brasileira. Rio de Janeiro: Codecri, 1976 (Col. Edições do Pasquim, v. 6), apud FIUZA, Alexandre Felipe. Entre cantos e chibatas: a pobreza em rima rica nas canções de João Bosco e Aldir Blanc. Campinas, 2001, 271f. Dissertação (Mestrado) - Universidade Estadual de Campinas. Faculdade de Educação, p. 53. 
p. 53). No entanto, na opinião de Wisnik “...em algum lugar e de algum modo, a música mantém com a política um vínculo operante e nem sempre visível" (Wisnik, 2008, p. 114) e está presente na vida social e individual, combinando representações sociais e forças psíquicas.

Johnson informa que há evidências de que o estímulo auditivo atravessa a consciência trazendo emoções à tona ${ }^{71}$. Por este mesmo motivo, Wisnik sugere que o uso da música envolveria poder, vez que os sons trespassam a percepção do consciente e causam o que chama de reações sub e hiperliminares, lembrando aquelas provocadas pela propaganda, pelos rituais religiosos ou até mesmo durante um show de 'rock'. Considerando que a música nos permitiria provar a sensação de felicidade, alerta que esta possui qualidades para os mais variados usos e manipulações ${ }^{72}$ :

"Instrumento de trabalho, habitat do homem - massa, meio metafísico de acesso ao sentido para além do verbal, recurso de fantasia e compensação imaginária, meio ambivalente de dominação e de expressão de resistência, de compulsão repetitiva e de fluxos rebeldes, utópicos, revolucionários, 'a música é sempre suspeita', dizia um personagem de Thomas Mann em 'A montanha mágica'. Seu papel é decisivo na vida das sociedades primitivas, no cotidiano popular, e o Estado e as religiões não a dispensam. A prática da música pelos grupos sociais mais diversos envolve múltiplos e complexos indices de identidade e de conflito, o que pode fazê-la amada, repelida, endeusada ou proibida. Sendo sempre comprometida, é uma terra de ninguém ideológica" (Wisnik, In: Bosi, 2008, p. 115, grifo nosso).

A interferência do poder político sobre a expressão artística pode ser identificada mais facilmente na Antiguidade e na Idade Média,

71 JOHNSON, Bruce; CLOONAN, Martin. Dark Side of the Tune: Popular Music and Violence. Hampshire: Ashgate Publishing, 2008, p. 17.

72 WISNIK, José Miguel. Algumas Questões de Música e Política no Brasil. In: BOSI, Alfredo (org.). Cultura Brasileira, Temas e Situações. $4^{a}$ ed. $7^{\mathrm{a}}$ reimpressão. São Paulo: Editora Ática, 2008, p. 114-5. 
dada a influência do poder espiritual sobre a sociedade de modo ge$\mathrm{ral}^{73}$. Na Grécia o poder regeu a atividade musical. Damon (final do século V a.C), músico e mestre de Platão (428-347 a.C.), um dos primeiros teóricos a trabalhar a música no interesse do poder, influenciou os escritos de Platão sobre música, a teoria dos modos, seus benefícios e perigos para as virtudes e para o Estado, propondo, assim, a educação através da música para o progresso moral ${ }^{74}$.

Conforme discorre Mário de Andrade, a música grega era fortemente influenciada pelo ritmo e não podia ser considerada uma arte isolada, pois unia-se à dança e à poesia" . Ademais, "Aos Modos, Gêneros e Ritmos davam poderes morais diferentes. Uns eram virilizadores, outros sensuais, outros enervantes etc... Chamam de 'Ethos' a esses caracteres morais da música" (Andrade, 2003, p. 28). Os modos no mundo Antigo, cujos nomes teriam se originado das regiões de onde provinham, constituíam escalas ligadas a ideais e, portanto, possuíam cunho simbólico ${ }^{76}$.

Na medida em que cada modo possuía um caráter moral, um valor ético específico, entendia-se que a música poderia influenciar os costumes, apresentando riscos à vida política e social ${ }^{77}$ e, por esse motivo, determinados ritmos, melodias, timbres e instrumentos deveriam ser excluídos ou regulados ${ }^{78}$. O Professor Arnaldo Daraya Con-

73 ANDRÉANI, Éveline. A música e suas relações com o universo político. In: MORIN, Edgar (org.). A Religação dos Saberes. O desafio do século XXI. $6^{\text {a }}$ ed. Rio de Janeiro, 2007, p. 332.

74 CANDÉ, Roland de. História Universal da Música. $2^{\mathrm{a}}$ ed. São Paulo: Martins Fontes, 2001, p. 72-4.

75 ANDRADE, Mário de. Pequena História da Música. 10ª ed. Belo Horizonte: Editora Itatiaia, 2003, p. 28-9.

76 COTTE, Roger J.V. Música e Simbolismo. Ressonâncias Cósmicas dos Instrumentos e das Obras. São Paulo: Editora Cultrix, 1997, p. 37.

77 CONTIER, Arnaldo Daraya. Arte e Estado: música e poder na Alemanha dos Anos 30. In: Sociedade \& Cultura. Revista Brasileira de História. São Paulo. ANPUH / Marco Zero, v. 8, n. 15, setembro de 1987 / fevereiro de 1988, p. 112.

78 ANDRÉANI, Éveline. A música e suas relações com o universo político. In: MORIN, Edgar (org.). A Religação dos Saberes. O desafio do século XXI. $6^{\text {a }}$ ed. Rio de Janeiro: Bertrand Brasil, 2007, p. 333. 
tier, referência no País nos estudos dos elos entre a atividade musical e poder, observa que ${ }^{79}$ : "A partir dessa problemática, a técnica musical sempre se apoiou num determinado sistema implicitamente ligado a valores culturais e ideológicos, variando conforme o momento histórico" (1987-8, p. 112).

A função político-pedagógica da música e a busca da música adequada à ordem social, em oposição à música desagregadora, foram objeto das discussões de Platão ${ }^{80}$. Influenciadas pelos ensinamentos de Damon e dos pitagóricos, as diretivas musicais de Platão estão registradas em obras como "A República" e "O Banquete". A compositora e professora da Universidade Paris-VIII, Éveline Andréani, observa que ${ }^{81}$ :

"Mas é a Platão que cabe a maior clareza sobre a relação entre poder e sistema musical. Ele expõe suas teorias didáticas na República, III, 398: '(A música) será um dos graus conduzindo à filosofia e, depois disso, um fator muito importante no desenvolvimento da vida civica. Um ensinamento teórico colocará o cidadão em condições de escolher as boas melodias e os ritmos apropriados. A consequência natural disso é que cada modo, cada ritmo deverão ser examinados por homens competentes: os que não puderem servir de forma útil serão eliminados.' Seu pensamento sobre as instituições aparece ainda mais claramente numa outra passagem da mesma obra (IV, 424): 'As melodias e os ritmos, uma vez fixados pelos dirigentes, não poderão ser modificados, pois toda modificação ou inovação acarretaria uma perturbação no Estado" (Andréani, In: Morin, 2007, p. 333, grifo nosso).

79 CONTIER, Arnaldo Daraya. Arte e Estado: Música e Poder na Alemanha dos Anos 30. In: Sociedade \& Cultura. Revista Brasileira de História. São Paulo. ANPUH / Marco Zero, v. 8, n. 15, setembro de 1987 / fevereiro de 1988, p. 112.

80 WISNIK, José Miguel. O Som e o Sentido - Uma Outra História das Músicas. $2^{\text {a }}$ ed. São Paulo: Companhia das Letras, 2006, p. 103.

81 ANDRÉANI, Éveline. A música e suas relações com o universo político. In: MORIN, Edgar (org.). A Religação dos Saberes. O desafio do século XXI. $6^{\text {a }}$ ed. Rio de Janeiro: Bertrand Brasil, 2007, p. 333. 
Mais adiante, durante a Idade Média, as autoridades eclesiásticas também regularam a música de forma a excluir o que lhes parecesse prejudicial. Inicialmente foram aceitos tão somente os sons das vozes contíguas do cantochão (canto monofônico e uníssono, originalmente sem acompanhamento, presente nas liturgias cristãs ${ }^{82}$ ). $\mathrm{O}$ trítono, por exemplo, intervalo de três tons, conhecido como "diabolus in musica" deveria ser evitado ${ }^{83}$. Andreáni observa que as intervenções de Platão surgiram em um cenário político de decadência do Estado ateniense, em que se propunham a manutenção e a conservação da ordem, enquanto que as primeiras autoridades religiosas cristãs logo de início tomaram as rédeas dessa manifestação artística, pois se tratava de estabelecer uma ordem ${ }^{84}$ :

"E, periodicamente, o poder, no caso do cristianismo ainda novo, ao passo que conservador no caso de Atenas, 'limpa' essas estruturas em nome da ideologia que ele deve instaurar ou defender, o que implica uma escolha e, portanto, um certo número de recusas" (Andréani, In: Morin, 2007, p. 334, grifo nosso).

Por volta do século XII, as autoridades religiosas cristãs gradualmente perderam força no universo político. A música também sofreu mudanças nesse período, com o surgimento da polifonia e o alongamento das sílabas, e desvencilhou-se do controle religioso. A partir de então, as conexões da música e poder se tornam mais difíceis de analisar. Andréani lembra, no entanto, que no século XV a música na Itália serviu para afirmar o poder dos pequenos potentados, enquanto que, na França de Luis XIV, um dos propósitos da música foi o de divertir a corte e atrair as forças do país para o rei ${ }^{85}$.

82 DICIONÁRIO Grove de Música. Rio de Janeiro: Jorge Zahar Ed., 1994, p. 166. WISNIK, José Miguel. O Som e o Sentido - uma outra história das mú-

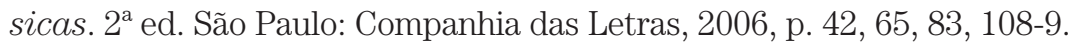

84 ANDRÉANI, Éveline. A música e suas relações com o universo político. In: MORIN, Edgar (org.). A Religação dos Saberes. O desafio do século XXI. $6^{\text {a }}$ ed. Rio de Janeiro: Bertrand Brasil, 2007, p. 333-4.

85 ANDRÉANI, Éveline. A música e suas relações com o universo político. In: MORIN, Edgar (org.). A Religação dos Saberes. O desafio do século XXI. $6^{\text {a }}$ ed. Rio de Janeiro: Bertrand Brasil, 2007, p. 332, 338-341. 
O historiador Eric Hobsbawm observa que no final do século XIX os regimes políticos passaram a travar uma guerra silenciosa pelo controle de símbolos e ritos dentro de suas fronteiras, e aponta que ${ }^{86}$ :

"De todos esses símbolos, talvez o mais poderoso tenha sido a música, em suas formas políticas de hino nacional e marcha militar - ambas executadas com grande entusiasmo, nessa época de J. P. Souza (1854-1932) e Edward Elgar (1857-1934)..." (Hobsbawm, 2009a, p. 173, grifo nosso).

As artes, de modo geral, no final do século XIX, conforme adverte Hobsbawm, devem ser entendidas em função da necessidade social de proverem conteúdo espiritual para uma sociedade materialista burguesa. Tomavam, no entender de Hobsbawm, o lugar de religiões tradicionais, especialmente entre os povos germânicos, para quem a cultura constituía um 'monopólio especial'. As óperas e teatros transformaram-se em templos para os cultos desta nova religião. Richard Wagner (1818-1883), apercebendo-se desta função e da relevância das artes para a religião do nacionalismo, na qual símbolos como bandeiras e hinos representam a nação, construiu em Bayreuth o que Hobsbawm designa de 'catedral', local em que todas as artes pudessem estar juntas, a designada fusão das artes ou 'obra de arte total'\$7:

"Wagner mostrava assim sua lucidez não apenas em perceber a conexão entre sacrifício e exaltação religiosa, mas também em entender a importância das artes como portadoras da nova religião laica do nacionalismo. Pois o que mais, exceto os exércitos, poderia expressar melhor esse conceito ilusório de nação do que símbolos da arte-primitiva, como nas bandeiras e hinos, elaborada e profunda, como naquelas escolas nacionais de música que tão intimamente se identificaram com as nações de nosso período no seu momento de aquisição de uma consciência coletiva, independência ou unificação..." (Hobsbawm, 2009b, p. 429, grifo nosso).

86 HOBSBAWM, Eric J. A Era dos Impérios. 1875-1914. 13ª ed. São Paulo: Ed. Paz e Terra, 2009, p. 172-3.

87 HOBSBAWM, Eric J. A Era do Capital. 1848-1875. 15a ed. São Paulo: Ed. Paz e Terra, 2009, p. 428-9, 435-6, 448. 
Contier descreve como o desenvolvimento urbano e o acirramento do conflito de classes, no final do século XIX e no início do século XX, especialmente na Itália e na Alemanha, teriam levado os próprios compositores, como foi o caso de Richard Wagner, a apoiar-se no Estado e nas questões nacionalistas para divulgar seus trabalhos, baseados na cultura popular e sua representatividade de uma 'raça': "Começava a haver na História da Música uma nova preocupação dos compositores no sentido de conciliar o estético com o ideológico, procurando atingir a 'nação' como um todo" (Contier, 1987-8, p. 111). Nesse processo, o Brasil também esteve representado um pouco mais tarde na figura do compositor Heitor Villa-Lobos (1887-1959). A música assume assim o papel de símbolo de ideais coletivos e de valores, expressos de forma explícita em hinos nacionais, cantos patrióticos e óperas de caráter nacionalista, dentre outros ${ }^{88}$.

O professor Contier ensina também que até o começo do século $\mathrm{XX}$, as músicas produzidas por compositores das mais variadas correntes estéticas foram executadas e criticadas de forma bastante livre. Com a Revolução Russa de 1917, no entanto, artistas e intelectuais recorreram à arte para transmitir suas ideias de transformação política e social. Os regimes totalitários ${ }^{89}$ nazista e soviético, por sua vez, ao constatarem a força da arte na divulgação de ideais políticos, criaram órgãos de controle e censuraram as manifestações artísticas de modo geral (e a música em particular, de forma sistemática ${ }^{90}$ ): "O Estado

88 CONTIER, Arnaldo Daraya. Arte e Estado: música e poder na Alemanha dos anos 30. In: Sociedade \& Cultura. Revista Brasileira de História. São Paulo. ANPUH / Marco Zero, v. 8, n. 15, setembro de 1987/fevereiro de 1988, p. 111.

Totalitarismo: Hannah Arendt entende que existiram apenas duas formas autênticas de domínio totalitário, a ditadura nacional - socialista alemã, iniciada em 1938, e a ditadura bolchevique que teve início em 1930, e que diferem de outras formas de opressão política como a ditadura, o despotismo e a tirania. O totalitarismo destrói tradições sociais, legais e políticas do país e transforma as classes em massas. Ademais, utiliza-se do Estado como fachada e o centro do poder é transferido para a polícia secreta. Vide: ARENDT, Hannah. Origens do Totalitarismo. São Paulo: Companhia das Letras. 1989, p. 470-486, 512-3.

90 ROSSELLI, John. Censorship. Grove Music Online. Item 2, Disponível em: <http://www.oxfordmusiconline.com:80/subscriber/article/grove/music/ 40602>. Acesso em: 04/09/2009. 
Totalitário, diante do caráter polissêmico e coletivista da música, considerava que ela poderia transformar a multidão numa massa 'perturbadora da ordem"' (Contier, 1987-8, p. 108). Contier invoca as lições de T. W. Adorno (1903-1969), para quem as estruturas sociais estão reproduzidas internamente na música, cujos múltiplos sentidos e a faculdade de empolgar multidões constituiria uma potencial ameaça aos regimes totalitários (e a seus princípios ideológicos nacional-socialistas) ${ }^{91}$.

Os regimes autoritários surgidos nas décadas de 1920-30, na visão de Contier, retomaram conceitos originados na Grécia Antiga e buscaram amarras ao caráter polissêmico da música, impondo sua leitura única, através de projetos culturais oficiais, no momento em que o rádio e os discos ganhavam expressão. A música inspirada na cultura popular, especialmente na União Soviética e na Alemanha, representava a disciplina, o trabalho e a sociedade organizada ${ }^{92}$. Ademais, ambos os regimes estimularam apresentações vocais coletivas, o culto de seus líderes, o retorno a valores musicais tradicionais e excluíram o jazz e a música contemporânea (e, no caso da Alemanha, a música com raízes judaicas $)^{93}$.

Convém ter em mente também, conforme observa Hobsbawm, que no século XX os avanços tecnológicos produziram uma revolução nas artes, tornando-as onipresentes, e que tais avanços tecnológicos tiveram consequências não só culturais, mas também políticas. Para Hobsbawm, a arte mais afetada pelo rádio foi a música que se liberou das limitações mecânicas e acústicas que restringiam sua disseminação ${ }^{94}$.

91 CONTIER, Arnaldo Daraya. Arte e Estado: música e poder na Alemanha dos anos 30. In: Sociedade \& Cultura. Revista Brasileira de História. São Paulo. ANPUH / Marco Zero, v. 8, n. 15, setembro de 1987 / fevereiro de 1988, p. 107-113.

92 CONTIER, Arnaldo Daraya. Arte e Estado: música e poder na Alemanha dos anos 30. In: Sociedade \& Cultura. Revista Brasileira de História. São Paulo. ANPUH / Marco Zero, v. 8, n. 15, setembro de 1987/fevereiro de 1988, p. 110-113.

93 ROSSELLI, John. Censorship. Grove Music Online. Itens 1 e 2, Disponível em: <http://www.oxfordmusiconline.com:80/subscriber/article/grove/ music/40602>. Acesso em: 04/09/2009.

94 HOBSBAWM, Eric J. Era dos Extremos. O breve século XX 1914-1991. $2^{a}$ ed. São Paulo: Companhia das Letras, 2009, p. 195, 484. 
A ideologização da música, presente nos regimes totalitários soviético e nazista, resultou no rigoroso controle de toda a atividade cultural (aí incluída a música) pelo Estado, que assumiu o controle dos meios de comunicação de massa. A música e a arquitetura foram especialmente visadas por Hitler" ${ }^{95}$ que em sua obra, "Minha Luta", chegou mesmo a chamá-las de "as duas rainhas entre as artes"

"A música aflorava como uma imagem em movimento, simbolizando a 'alma viva' da Nação e as 'raízes' espirituais do povo. Em geral as músicas adquiriam um caráter grandiloquente, buscando empolgar as multidões dentro de um 'novo espirito'. Agora, a música se transfigurava num discurso político, identificando-se com o próprio Estado, que, em principio, deveria se 'aperfeiçoar', tornando-se, num determinado momento da História, uma verdadeira 'obra de arte"” (Contier, 1987-8, p. 114, grifo nosso).

Com o final da $2^{\text {a }}$ Guerra, os norte-americanos implantaram na Alemanha políticas de desnazificação e reeducação, que também incluíam a música. Foram vetados inclusive alguns compositores como Richard Strauss (1864-1949), Hans Pfitzner (1869-1949) e Jean Sibelius (1865-1957), conforme nos relata o premiado crítico de música norte-americano, Alex Ross ${ }^{97}$. As políticas relativas à música fizeram parte de um documento designado "Instrução para Controle Musical no 1" disponível nos Arquivos Nacionais situados no College Park, em Maryland, Estados Unidos. Ross cita alguns trechos, a saber:

95 CONTIER, Arnaldo Daraya. Tragédia, Festa, Guerra: os coreógrafos da modernidade conservadora. In: Revista USP / Dossiê 50 anos de Final de Segunda Guerra. Coordenadoria de Comunicação Social, Universidade de São Paulo, n. 26, junho/agosto 1995. São Paulo: USP, CCS, p. 22, 34 e 41; e, CONTIER, Arnaldo Daraya. Arte e Estado: música e poder na Alemanha dos anos 30. In: Sociedade \& Cultura. Revista Brasileira de História. São Paulo. ANPUH / Marco Zero, v. 8, n. 15, setembro de 1987 / fevereiro de 1988, p. 114.

HITLER, Adolf. Mein Kampf - "Minha Luta" s.l.: Editora Verídica, 1969, p. 30 e 199.

97 ROSS, Alex. O Resto é Ruído. Escutando o século XX. São Paulo: Companhia das Letras, 2009, p. 368. 
"'É de fundamental importância', diz o memorando, 'que não passemos a impressão de que estamos tentando controlar a cultura da mesma forma que os nazistas'. Em vez disso 'a vida musical na Alemanha deve ser influenciada de maneira positiva e não de maneira negativa, ou seja, estimulando a música que consideramos benéfica e impedindo o acesso à que consideramos perigosa' .... Com essa abordagem bifurcada, o documento conclui: 'Teremos pouca dificuldade em imprimir uma direção internacional positiva na vida musical alemã ”' (Ross, 2009, p. 368, grifo nosso).

No Brasil, durante o Estado Novo (1937-1945), a relação entre música e política tornou-se evidente. O ufanismo nacionalista conjugado com a exaltação ao trabalho, que serviram de fundamento à propaganda, configuraram uma política de subvenção estatal da música para a mobilização das massas e educação política. Nessa época, foi implantado o canto orfeônico nas escolas ${ }^{98}$ :

"É durante esse episódio que Villa-Lobos leva adiante o programa de implantação do canto orfeônico nas escolas do Pais, tomando a atividade coral como um veículo de introjeção do sentimento de autoridade. A malandragem sambistica, nesse contexto, aparece como um mal a ser erradicado, como ruído e dissonância destinados a serem resolvidos num acorde coral" (Wisnik, In: Bosi, 2008, p. 120, grifo nosso).

O projeto de valorização do ensino do canto orfeônico como base de formação cívica ${ }^{99}$, fortemente influenciado pela questão nacional (inspirado na Alemanha nazista e difundido em tantos outros países, como a União Soviética, França, Estados Unidos, Hungria), estava imbuído de um implícito caráter disciplinador. Atendia a inte-

98 WISNIK, José Miguel. Algumas Questões de Música e Política no Brasil. In: BOSI, Alfredo (org.). Cultura Brasileira, Temas e Situações. $4^{\mathrm{a}}$ ed. $7^{\mathrm{a}}$ reimpressão. São Paulo: Editora Ática, 2008, p. 120.

CONTIER, Arnaldo Daraya. O Ensaio sobre a Música Brasileira: estudo dos matizes ideológicos do vocabulário social e técnico-estético (Mario de Andrade, 1928). In: Revista Música. São Paulo: Departamento de Música da ECA-USP, v. 6, n. 1/2 - maio/novembro 1995, p. 75-121. 
resses não só de educadores, mas também de políticos interessados na consolidação da 'República Nova' (1930) e do ‘Estado Novo' (1937). Reuniam-se as massas em torno de um ideal de nação, em verdadeiros "espetáculos cívico-artísticos", na expressão do professor Contier, em que hinos ufanistas formavam o eixo dos programas cívicocomemorativos $^{100}$. O Jornal Valor Econômico reproduz a seguinte frase atribuída a Carlos Drummond de Andrade (1902-1987) referindo-se a Villa-Lobos ${ }^{101}$ :

"Quem o viu um dia comandando o coro de 40 mil vozes adolescentes no estádio do Vasco da Gama não pode esquecê-lo nunca. Era a fúria organizando-se em ritmo, tornando-se melodia e criando a comunhão mais generosa, ardente e purificadora que se poderia conceber" (Lorenzotti, 2009, p. 16).

Órgãos governamentais no Brasil foram incumbidos de coordenar e supervisionar as atividades musicais. A Superintendência da Educação Musical e Artística (SEMA) foi criada em 1932 para implantar o canto orfeônico. Suas diretrizes incluíam o ensino da música como veículo de propagação de civismo, além de ser responsável pela correta execução de hinos oficiais e por estimular o gosto por canções cívicas e artísticas. Mais tarde, em 1939, ao Departamento de Imprensa e Propaganda (DIP) foi atribuída a tarefa de fiscalizar e controlar as atividades artísticas e de censura e de privilegiar a música nacionalista como instrumento de propaganda política ${ }^{102}$.

A censura no Brasil durante o regime militar ainda vive na memória dos brasileiros. O campo musical, especialmente a Música Po-

100 CONTIER, Arnaldo Daraya. Passarinhada do Brasil: canto orfeônico, educação e getulismo. Revisão Técnica: Maria Aparecida de Aquino. Bauru, SP: Editora da Universidade do Sagrado Coração, 1998, p. 22-26, 32-33, 36, 65-69.

101 LORENZOTTI, Elizabeth. Valor. São Paulo, 27 de fevereiro de 2009. Caderno EU\&, p. 16.

102 CONTIER, Arnaldo Daraya. Passarinhada do Brasil: canto orfeônico, educação e getulismo. Revisão Técnica: Maria Aparecida de Aquino. Bauru, SP: Editora da Universidade do Sagrado Coração, 1998, p. 29-30, 51-55. 
pular Brasileira, foi alvo de vigilância e as canções e suas letras (estas, o foco de toda a censura ${ }^{103}$ ), bem como seus compositores, intérpretes e 'performances', vistos com suspeita ${ }^{104}$. O desabafo da ex-ministra e atual presidente, Dilma Rousseff, em entrevista à Folha de São Paulo, bem expressa o clima da época: "Com o passar do tempo, o Brasil foi se fechando, as coisas foram ficando cada vez mais qualificadas como subversivas. Era subversivo até uma música..."105 (Odilla, 2009). A canção brasileira nesse período esteve sob os holofotes da censura, no entanto ${ }^{106}$ :

"Atravessou os periodos mais obscuros dos anos $70 \mathrm{com}$ grande força, opondo à repressão uma poética da afirmação da vida pela assunção do corpo pleno, extraindo a sua força política do Eros dançante e da beleza do canto" (Wisnik, In: Bosi, 2008, p. 123).

\subsection{MÚSICA, POLÍTICA E VIOLÊNCIA}

Johnson e Cloonan ensinam que a cumplicidade da música com o poder, especialmente da música popular, constitui um truísmo; e a

${ }^{103}$ A censura na música está geralmente focada nas palavras, ou seja, na música que se alia a palavras, o que inclui o teatro musical e a música com associações políticas (marchas com textos nacionalistas ou revolucionários e canções de cabaré) com forte apelo à concentração do público, sendo considerada fonte de subversão e violência. Cf.: ROSSELLI, John. Censorship. Grove Music Online. Disponível em: <http://www.oxfordmusiconline.com:80/subscriber/article/grove/music/40602>. Acesso em: 04/09/2009.

${ }^{104}$ NAPOLITANO, Marcos. A MPB sob suspeita: a censura musical vista pela ótica dos serviços de vigilância política (1968-1981). Revista Brasileira de História, v. 24. n. 47. São Paulo, 2004. Disponível em: <http://www. scielo.br/scielo.php?script=sci_arttext\&pid $=$ S0102-01882004000 100005 > . Acesso em: 24/08/2009.

${ }^{105}$ ODILLA, Fernanda. Dilma diz não ter a mesma cabeça da época em que era guerrilheira. Folha Online, 5 de abril de 2009. Disponível em:

$<$ http://tools.folha.com.br/print?site=emcimadahora\&url=http\%3A\%2F \%2Fwww1.folha.uol...>. Acesso em: 07/04/2009.

${ }^{106}$ WISNIK, José Miguel. Algumas Questões de Música e Política no Brasil. In: BOSI, Alfredo (org.). Cultura Brasileira, Temas e Situações. $4^{\mathrm{a}}$ ed. $7^{\mathrm{a}}$ reimpressão. São Paulo: Editora Ática, 2008, p. 123. 
luta pelo direito de fazer ruído, uma das formas de traçar as relações entre música e violência ${ }^{107}$ :

"A história do direito de fazer ruido ou impor silêncio, e do direito de descrever o som como lexicamente inteligível, o discurso como aceitável, e o ruído como música, fornece o contexto histórico e cultural para uma apreciação da interação entre música e violência na era moderna" (Johnson; Cloonan, 2008, p. 38).

Afirmam os autores que o som é instrumento não só de poder, mas também de violência, ou mesmo a causa desta, cuja presença e capacidade ampliaram-se expressivamente no século XX, auxiliadas pelo desenvolvimento da tecnologia, ganhando notoriedade em diversas formas de confronto. Ademais, reportam-se aos que reconhecem que a violência está nos alicerces da política, como Mao Tsé-Tung (1893-1976) que declarou que "o poder brota do cano de uma arma" e Max Weber (1864-1920) para quem o Estado é a entidade que possui o monopólio da violência legítima ${ }^{108}$. A propósito, essa visão, conforme referido no início deste trabalho, foi contestada por Hannah Arendt, para quem a violência tem natureza instrumental, depende de implementos e surge quando o poder está em risco. O poder, por sua vez, consistiria na capacidade de agir em concerto e o fato de a violência e o poder andarem de mãos dadas não significa que sejam equivalentes ${ }^{109}$.

Vale notar que, de modo geral, todas as culturas empregam a música como recurso para integração e unificação, bem como para estabelecer divisões e fronteiras, inclusive internamente, demarcando diferentes subgrupos com base em critérios como faixa etária ou de ordem socioeconômica. Na medida em que são escolhidas determinadas exclusões, um grupo social se une e contrapõe-se a outro. Tal

107 JOHNSON, Bruce; CLOONAN, Martin. Dark Side of the Tune: popular music and violence. Hampshire: Ashgate Publishing, 2008, p. 4, 38 e 44.

108 JOHNSON, Bruce; CLOONAN, Martin. Dark Side of the Tune: popular music and violence. Hampshire: Ashgate Publishing, 2008, p. 146-9.

109 ARENDT, Hannah. Sobre a Violência. Rio de Janeiro: Ed. Civilização Brasileira, 2009, p. 26, 51, 58-69. 
manipulação foi empregada de forma explícita na Alemanha nazista (que baniu a música produzida por judeus e a chamada 'música degenerada ${ }^{110}$ ) e nos países integrantes do bloco comunista, conforme visto, inclusive, na Seção anterior. Atualmente, o processo de globalização realça a heterogeneidade e a música, como instrumento para o confronto cultural, ganha expressão ${ }^{111}$ :

"A estreita associação da música com a sociedade, e seu papel na interação entre grupos étnicos e nações, pode consistir remanescência da função de sons pré-musicais nos primórdios da civilização, em que grupos sociais teriam impressionado (ou assustado?) uns aos outros com o uso organizado da potência do som" (Nettl, Grove, item 5).

Johnson e Cloonam apontam que esta característica menos evidente da música, de natureza dicotômica, i.e., sua qualidade para demarcar um território (individual ou de uma comunidade), e que resulta, em contrapartida, na invasão, marginalização ou destruição daquele pertencente a outros, diz respeito ao controle sobre a música e constitui ponto nevrálgico. Conforme constataram nas diversas situações que analisaram, a imposição de música da escolha de determinada pessoa sobre outra geralmente constitui forma de violência, em maior ou menor grau, em qualquer sociedade. Esse aspecto da música e sua associação com a violência, conforme admitem, requer uma análise que vai muito além da estética musical, para incluir, por exemplo, a fisiologia da escuta, a psico e a bioacústica e estudos de paisagem sonora, bem como a história da cultura, a semiótica, a etnografia e a

${ }^{110}$ Esta terminologia foi adotada pelos nazistas nos anos 1920, para se referir às manifestações culturais que representariam em seu entender sintomas do declínio nacional, e incluía música atonal, jazz e a música de compositores de origem judaica, mas que acabou por abranger diversos estilos musicais considerados inaceitáveis pelo regime. Cf. LEVI, Erik. Entartete Music (Ger.: "Degenerate Music") Grove Music Online. Disponível em: $<$ http://www.oxfordmusiconline.com:80/subscriber/article/grove/ music/45065>. Acesso em: 14/11/2009.

${ }^{111}$ NETTL, Bruno. Music. Grove Music Online, item 5. Disponível em: $<$ www.oxfordmusiconline.com:80/subscriber/article/grove/music/ 40476>. Acesso em: 29/08/2009. 
etnologia. Outrossim, para se conhecer o que designam de 'lado negativo da música', é necessário referir o seu 'lado positivo', sendo certo que a musicoterapia também pode auxiliar na compreensão desta questão. Reconhecem que a música pode acompanhar ou incitar violência, entre nações, tribos, entre o Estado e a população e vice-versa, inclusive no ostracismo ou na punição de indivíduos, e cada vez mais a música associada à violência é patrocinada pelo Estado ${ }^{112}$.

A música e outras sonoridades associadas à violência não são um fenômeno da contemporaneidade. Narrativas históricas, religiosas e mesmo míticas sugerem "o que parece ser um fascínio universal com o potencial da música como uma arma"113 (Johnson, 2009). Esse potencial devastador é relatado por Ulisses (Homero) ao enfrentar o canto das sereias que conduziria os marinheiros à morte, e cuja conexão com o perigo resultou assentada na palavra 'sirene'(a) ${ }^{114}$ (instrumento sonoro para dar alarma ${ }^{115}$ ). A mitologia grega nos legou Pã, criatura semi-humana, dotada de chifres, rabo e pés de cabra, que criou sua conhecida flauta, após perseguir sua ninfa (Sirinx), transformada em uma touceira de junco para escapar do fauno ${ }^{116}$. Sua música e súbitas aparições assustavam pastores e passantes e, daí, a origem da palavra 'pânico', um susto ou medo sem motivo determinado ${ }^{117}$.

112 JOHNSON, Bruce; CLOONAN, Martin. Dark Side of the Tune: popular music and violence. Hampshire: Ashgate Publishing, 2008, p. 4, 10-12, 24-26, 37.

113 JOHNSON, Bruce. Musical torture has pedigree of mythic proportions. National Times. Society and Culture. Theage.com.au. 29 de outubro de 2009. Disponível em: <http://www.theage.com.au/opinion/society-andculture/musical-torture-has-pedigree-of-mythic-proportions-20091027hhb8.html>. Acesso em: 02/11/2009.

114 JOHNSON, Bruce; CLOONAN, Martin. Dark Side of the Tune: popular music and violence. Hampshire: Ashgate Publishing, 2008, p. 31.

115 NOVO Dicionário Aurélio da Língua Portuguesa. $3^{\text {a }}$ ed. Curitiba: Ed. Positivo, 2004, p. 1855.

116 PICKERING, Fran. Encyclopedia of Animals in Nature, Myth and Spirit. Great Bretain: The Element Illustrated, 1999, p. 136-137; e, FONTERRADA, Marisa Trench de Oliveira. Música e Meio Ambiente. Ecologia sonora. São Paulo: Irmãos Vitale, 2004, p. 66.

117 DICIONÁRIO Houaiss de Língua Portuguesa. Instituto Antonio Houaiss de Lexicografia. $1^{\text {a }}$ ed. Rio de Janeiro: Editora Objetiva Ltda., 2001, p. 2117-8. 
Um dos primeiros relatos na cultura ocidental do uso do som na guerra é encontrado na Bíblia, quando Josué liderou um ataque a Jericó em torno de 1.400 a.C. e os muros da cidade ruíram ao som de gritos e das trombetas (Josué 6:4). A Bíblia garante ainda que o final dos tempos será ruidoso com o toque das sete trombetas e as desgraças acompanhadas de gritos e trovões que cairão sobre a Terra (Apocalipse). Na visão da religião Cristã, a música no Inferno (em contraposição à música Celestial) seria, no mais das vezes, ruidosa e dissonante com o propósito de aumentar a agonia dos condenados e encorajar os algozes, embora para alguns o inferno da religião Cristã se caracterizaria pelo silêncio completo, ou mesmo a música sedutora e hipnótica é que faria parte dos domínios do demônio ${ }^{118}$. A preocupação com o poder hipnótico da música (especialmente da ópera de Wagner) está na obra de Lev Tolstoi (1828-1910) ${ }^{119}$. Oliver Sacks bem assinalou que "O tema da música sedutora mas perigosa sempre despertou a imaginação" (2007, p. 282) $)^{120}$.

Os cantos ou gritos de guerra são, possivelmente, o mais antigo e explícito uso de sonoridades a serviço do combate e da violência ${ }^{121}$ :

"Havia [...] fatores que parecem triviais para serem lembrados, mas que provaram ser de grande importância à época da ação. O grito de guerra Romano era mais alto e mais aterrorizante porque era em unissono, enquanto que os gritos do lado dos Cartagineses eram discordantes, emanando de uma variedade de pessoas com diversas línguasmãe" (Livy, 1965, apud Johnson; Cloonan, 2008, p. 33-4).

118 WILKINS, Nigel. The Devil's Music. Goldberg: Early Music Magazine. East Sussex, n. 14, 2001, p. 48-59; LA MUSIQUE, Repères Iconographiques. Paris: Editions Hazan, 2006, p. 78-83, 165-167.

119 TOLSTÓI, Lev. O que é Arte? . São Paulo: Ediouro, 2002, p. 184-7; TOLSTÓI, Lev. A Sonata a Kreutzer. $1^{\text {a }}$ ed., São Paulo: Editora 34, 2007, p. 83.

120 SACKS, Oliver. Alucinações Musicais: relatos sobre a música e o cérebro. São Paulo: Companhia das Letras, 2007, p. 282.

121 JOHNSON, Bruce; CLOONAN, Martin. Dark Side of the Tune: popular music and violence. Hampshire: Ashgate Publishing, 2008, p. 33-4; PIESLAK, Jonathan R. Sound Targets. American Soldiers and Music in the Iraq War. Bloomington: Indiana University Press, 2009, p. 46. 
Os cantos e gritos de guerra subsistem nas manifestações das torcidas e nas operações policiais, como é o caso dos gritos do conhecido Batalhão de Operações Especiais - BOPE (PM/RJ). A canção "Tropa de Elite", composta pela banda Tihuana, em 1999 ("Tropa de Elite, osso duro de roer/Pega um, pega geral, também vai pegar você"), já fazia sucesso entre os militares desde o início da década por levantar o moral das tropas"122. O cineasta produtor do filme "Tropa de Elite", José Padilha, declarou em entrevista ao Programa Roda Viva da TV Cultura, em 2007, que a música do filme é aquela utilizada pela polícia para subir o morro ${ }^{123}$.

O musicólogo David Tame reporta que a música marcial (com bandas de tambores e cornetas) foi usada desde a alvorada dos tempos para alcançar efeitos práticos duplos, quais sejam, inspirar um grupo de pessoas e atemorizar outro. Nota que a música marcial dos vitoriosos foi muitas vezes adotada pelos derrotados, ainda que estranha à sua cultura, por reconhecerem a sua importância na vitória e cita os Cruzados que, vencidos pelos sarracenos, passaram a utilizar tons marciais árabes ${ }^{124}$.

A música, bem como outras sonoridades, também tem integrado demonstrações públicas da aplicação da justiça. Há relatos de acompanhamento instrumental nas procissões destinadas a humilhar membros de uma comunidade, de trombetas anunciando o percurso ao

122 THEOPHILO, Jan; ARAÚJO, Vera. "Gritos de Guerra do BOPE Assustam o Parque Guinle". O Globo, Rio de Janeiro, 24 de setembro de 2003. $1^{\circ}$ Caderno, p.1; PLANTA, Paulo. Tihuana canta Tropa de Elite e leva o público ao delírio. Cosmo On Line. Agência Anhanguera. Disponível em: $<$ www.cosmo.com.br/diversaoarte/integraasp?id=213798 $>$. Acesso em: 01/12/2007.

${ }^{123}$ PROGRAMA RODA VIVA. TV Cultura. Entrevista com José Padilha (cineasta) (DVD). 8 de outubro de 2007. Apresentação: Paulo Markun.

124 THAME, David. O Poder Oculto da Música. Um estudo da influência da música sobre o homem e sobre a sociedade, desde o tempo das antigas civilizações até o presente. São Paulo: Ed. Cultrix, 2006, p. 157. 
patíbulo e de sinos dobrando para os condenados e excomungados ${ }^{125}$. No Brasil, durante o período escravagista, não foi diferente ${ }^{126}$ :

"NAS CIDADES, os castigos de açoites eram feitos publicamente, nos pelourinhos. Eram colunas de pedra, velha tradição romana, que se erguiam em praça pública. Na parte superior, estas colunas tinham pontas recurvadas de ferro, onde se prendiam os condenados à forca. Mas o pelourinho tinha outros usos, além do da forca. Nele eram amarrados os infelizes escravos condenados à pena dos açoites.

O espetáculo era anunciado publicamente pelos rufos de tambor" (Ramos, In: Carneiro, 2005, p. 125, grifo nosso).

As modernas tecnologias acústicas permitiram a amplificação, disseminação e armazenamento dos sons e o espaço acústico tornouse zona de confronto, inclusive, entre o público e o privado. Adolf Hitler (1889-1945) bem se apercebeu desse poderio e inundou a Alemanha com sua voz e canções através do rádio e alto-falantes ${ }^{127}$ : "Ninguém demonstrou mais efetivamente do que Hitler a re-união da voz, música e poder através da tecnologia na era da modernidade" (Johnson; Cloonan, 2008, p. 62).

A efetiva documentação da trilha sonora utilizada em atos de violência costuma ser escassa. Mas existem assustadoras evidências do uso de música na Alemanha nazista para finalidades que extrapolam o propósito de fortalecer a cultura alemã. Acredita-se que uma das razões da tolerância de atividades musicais espontâneas nos guetos e mesmo nos campos de concentração foi a sua contribuição na manutenção da ordem, calma e submissão. Nos campos de concentração, a música do rádio ou do gramofone era irradiada por alto-falantes e, para quase todos os prisioneiros, o confronto com a música foi diário.

125 JOHNSON, Bruce; CLOONAN, Martin. Dark Side of the Tune: popular music and violence. Hampshire: Ashgate Publishing, 2008, p. 36-7.

${ }^{126}$ RAMOS, Arthur. Castigos de Escravos. In: CARNEIRO, Edison. Antologia do Negro Brasileiro: de Joaquim Nabuco a Jorge Amado. Rio de Janeiro: Agir, 2005, p. 125.

127 JOHNSON, Bruce; CLOONAN, Martin. Dark Side of the Tune: popular music and violence. Hampshire: Ashgate Publishing, 2008, p. 57, 61-63. 
Cantar canções sob coerção constituía parte da rotina ${ }^{128}$, sujeitando os prisioneiros a castigos físicos caso não atendessem aos comandos satisfatoriamente. A maioria dos campos de concentração possuía seus próprios hinos (e canções específicas), muitos dos quais compostos pelos prisioneiros por determinação dos seus dirigentes. Esses hinos eram cantados durante as atividades diárias e resultaram firmemente associados aos respectivos campos, assumindo caráter oficial ${ }^{129}$.

Além de apresentações musicais aos seus algozes e à guarda de elite ("SS") para a diversão e lazer destes, os prisioneiros eram forçados a cantar ou fazer apresentações musicais (e até orquestrais) durante as marchas diárias, trabalhos forçados, castigos e execuções, quando da chegada de novos prisioneiros ou a caminho da 'solução final'. São numerosos os exemplos de imposição da música e da obrigação de cantar (especialmente marchas, músicas patrióticas e canções alemãs bem conhecidas, repetidas à exaustão ${ }^{130}$ ) que teriam por finalidade a disciplina, a contagem, a ordem, a humilhação, a intimidação e mesmo uma variedade de propósitos sádicos. Neste tocante, conforme apontado por Hannah Arendt ${ }^{131}$, "o principal fator humano, em Auschwitz, era o sadismo e o sadismo é basicamente sexual" (Arendt, In: Naumann, [196?], p. 42). Há quem sustente que essas práticas musicais integrariam rituais com significado especial aos guardas da SS, permitindo uma teatralização de sua superioridade e sustentação de imagem e moral ante as suas insólitas atividades diárias. Ademais, considerando os registros existentes de práticas musicais

128 FACKLER, Guido. Music in Concentration Camps 1933-1945. Music \& Politics. University of California, Santa Barbara (UCSB), v. 1, n. 1 (Inverno de 2007). Disponível em: <http://www.music.ucsb.edu/projects/musicandpolitics/archive/2007-1/fackler.html>. Acesso em: 02/01/2009.

129 FACKLER, Guido. Concentration Camp Anthems. Music and the Holocaust. Disponível em: <www.holocaustmusic.ort.org/places/camps.camp/ anthems>. Acesso em: 15/04/2010.

130 FACKLER, Guido. Music in Concentration Camps 1933-1945. Music \& Politics. University of California, Santa Barbara (UCSB), v. 1, n. 1 (Inverno de 2007). Disponível em: <http://www.music.ucsb.edu/projects/musicandpolitics/archive/2007-1/fackler.html>. Acesso em: 02/01/2009.

131 ARENDT, Hannah. Introdução. In: NAUMANN, Bernd. Auschwitz, v. 1, Lisboa: Ed. Livros do Brasil, [196?], p. 12-47. 
forçadas em cinco dos seis campos de concentração especialmente destinados ao extermínio (i.e., Belzic, Sobibor, Treblinka, Majdanek e Auschwitz, excluído apenas Chelmno), as evidências sugerem uma política (e não uma iniciativa individual) no processo de aniquilação ${ }^{132}$.

Johnson e Cloonan concluem que a música serviu de trilha sonora à violência institucionalizada na Alemanha nazista. De um lado, prestou-se ao fortalecimento do movimento nazista e, de outro, para humilhar suas vítimas. Os autores relembram um trecho da obra do escritor e prisioneiro do holocausto Primo Levi (1919-1987), no qual descreve a música imposta aos prisioneiros em Auschwitz ${ }^{133}$ :

"As melodias são poucas, uma dúzia, as mesmas todos os dias, de manhã e ao anoitecer: marchas e canções populares caras a todo alemão. A mentira gravada em nossas mentes e que será a última coisa em Lager [campo de concentração] que esqueceremos: a voz da decisão dos outros de nos aniquilar primeiro como homens para poder nos matar mais lentamente depois [...] Que prova mais concreta de sua vitória" (Levi, 1979, apud Johnson; Cloonan, 2008, p. 72, grifo nosso).

A presença da música em campos de concentração representaria uma enorme contradição para alguns estudiosos, pois de que maneira a mais sublime expressão do espírito humano poderia estar envolvida no extermínio de milhões? Consistiria para alguns uma grotesca aberração ao que Johnson e Cloonan contrapõem 134: "a relação é mundana e onipresente, parte do potencial 'mal da banalidade', invertendo a formulação de Arendt" (2008, p. 73).

Hannah Arendt assistiu ao julgamento de Adolf Eichmann, em Israel, em 1961 (após ele ter sido capturado na Argentina em 1960), como correspondente da revista "The New Yorker". Escreveu o livro

132 GILBERT, Shirli. Music in the Holocaust: confronting life in the nazi ghettos and camps. Oxford: Oxford University Press, 2006, p. 148, 175-195.

133 JOHNSON, Bruce; CLOONAN, Martin. Dark Side of the Tune: Popular Music and Violence. Hampshire: Ashgate Publishing, 2008, p. 71-3.

134 JOHNSON, Bruce; CLOONAN, Martin. Dark Side of the Tune: Popular Music and Violence. Hampshire: Ashgate Publishing, 2008, p. 73. 
"Eichmann em Jerusalém - Um Relato sobre a Banalidade do Mal", no qual descreve suas impressões sobre a figura de Eichmann, que tomou parte na organização e administração da 'solução final'. Agiu de acordo com as regras, com meticulosidade burocrática, sem precisar recorrer à consciência, distante da realidade e de questões morais, alienação que, na opinião de Arendt, causa mais devastação do que todos os maus instintos juntos ${ }^{135}$.

Johnson e Cloonan afirmam que a guerra sempre propiciou a confluência do som, da música e da violência ${ }^{136}$. E o passado recente apenas confirma a asserção. A pesquisa e o desenvolvimento das novas tecnologias acústicas, de armamentos 'não letais' ${ }^{137}$ e ainda os estudos envolvendo psicologia na guerra e no cativeiro patrocinados por poderosas nações resultaram em novos usos do som e da música por militares e agências de inteligência, conforme analisado pelo historiador norte-americano, Alfred W. McCoy ${ }^{138}$. No Iraque, Afeganistão e Guantánamo a música não só exerceu um papel auxiliar nos ataques (a tomada de Fallujah, no Iraque, em 2004, pelos norte-americanos, foi acompanhada de bombardeio sonoro, revidado com rezas, cantos e música árabe irradiados por alto-falantes, sendo designada pelos militares de "LalaFallujah"139), como teve papel importante nas salas de interrogatórios, torturas e celas, no mais das vezes executada

135 ARENDT, Hannah. Eichmann em Jerusalém - Um Relato sobre a Banalidade do Mal. São Paulo: Companhia das Letras, 1999, p. 33, 67, 165-8, 209, 311-6.

136 JOHNSON, Bruce; CLOONAN, Martin. Dark Side of the Tune: Popular Music and Violence. Hampshire: Ashgate Publishing, 2008, p. 50.

${ }^{137}$ Em 1990, por ocasião do $8^{\circ}$ Congresso das Nações Unidas para a Prevenção do Crime e o Tratamento dos Delinqüentes, foram aprovados os "Princípios Básicos sobre a Utilização da Força e de Armas de Fogo pelos Funcionários Responsáveis pela Aplicação das Leis" que recomendam a busca de armamentos alternativos com o fim de limitar o recurso a meios que possam causar mortes ou lesões corporais.

${ }_{138}$ McCOY, Alfred W. A Question of Torture: Cia Interrogation from the Cold War to the War on Terror. $1^{a}$ ed. New York: Owl Books, Henri Holt and Company, LLC, 2006, p. 8.

139 PIESLAK, Jonathan R. Sound Targets. American Soldiers and Music in the Iraq War. Bloomington: Indiana University Press, 2009, p. 84-5. 
em alto volume e combinada com outras práticas (há, inclusive, denúncias de dança forçada ${ }^{140}$ ). Relatórios produzidos por entidades como a Cruz Vermelha ${ }^{141}$, "Physicians for Human Rights"142 e pela Comissão de Forças Armadas do Senado Norte-Americano ${ }^{143}$, assim como os processos e julgamentos envolvendo detidos em Guantánamo noticiados pela imprensa, fornecem extenso material sobre as práticas militares atuais envolvendo música e outros sons na guerra, nos interrogatórios e na tortura.

O Brasil teve oportunidade de conhecer de perto alguns desses procedimentos sonoros de cunho oficial enquanto o presidente hondurenho deposto, Manuel Zelaya, esteve abrigado na Embaixada Brasileira em Tegucigalpa ${ }^{144}$. Em outubro de 2009, o Brasil denunciou o assédio à Organização dos Estados Americanos (OEA), que divulgou texto em repúdio a essas práticas, consideradas desumanas e irracio-

${ }^{140}$ HAYNES, Deborah. Iraq detainees hooded, abused and forced to dance like Michael Jackson. The Times. 14 de julho de 2009, p. 13; e, PHYSICIANS for human rights. Broken Laws, Broken Lives. Medical Evidence of Torture by US Personnel and its Impact. Junho de 2008. Disponível em: <www.brokenlives.info/mp-admin/profile.php>. Acesso em: 19/06/2008; e, ANDERSSON, Hilary. Afghans 'abused at secret prison'. BBC News. 15 de abril de 2010. Disponível em: <http://newsvote.bbc. co.uk/mpapps/pagetools/print/news.bbc.co.uk/2/hi/south_asia/8621973. stm? $\mathrm{ad}=1>$. Acesso em: 18/04/2010.

${ }^{141}$ ICRC - International Committee of the Red Cross Regional Delegation for United States and Canadá. ICRC Report on the treatment of fourteen "high value detainees" in Cia Custody. 14 de fevereiro de 2007. Disponível em: <www.nybooks.com/articles/22614>. Acesso em: 18/04/2009.

${ }_{142}$ PHYSICIANS for Human Rights. Broken Laws, Broken Lives. Medical Evidence of Torture by US Personnel and its Impact. Junho de 2008. Disponível em: <www.brokenlives.info/mp-admin/profile.php>. Acesso em: 19/06/2008.

${ }^{143}$ REPORT of the Committee on Armed Services, United States Senate. Inquiry into the Treatment of Detainees in U.S. Custody. 20 de novembro de 2008. The New York Times. Disponível em: <http://documents.nytimes.com/report-by-the-senate-armed-services-committee-on-detaineetreatment\#p=1>. Acesso em: 24/04/2009.

144 RAMA, Anahí; ISRAEL, Esteban. Manifestantes pró e contra Zelaya saem às ruas de Tegucigalpa. OGloboOnline. 24 de setembro de 2009. Disponível em: <www.oglobo.globo.com>. Acesso em: 28/09/2009. 
nais e em violação a direitos humanos, por impedir o descanso e constituir tortura psíquica ${ }^{145}$.

A musicóloga e professora de música da Universidade de Nova Iorque, Suzanne G. Cusick, analisou o uso recente de armas acústicas e de música pelos norte-americanos nos campos de batalha e nos centros de detenção, especialmente música em alto volume, e concluiu que a utilização do som nos campos de batalha visa precipuamente produzir efeitos no corpo humano, enquanto que o seu uso nas salas de interrogatório tem por objetivo a destruição da subjetividade ${ }^{146}$. O historiador norte-americano Alfred W. McCoy informa que as atuais técnicas de interrogatório de natureza psicológica, designadas "torture light", foram codificadas na década de 1960 pela Agência Central de Inteligência Norte-Americana ('CIA') e aperfeiçoadas durante os recentes conflitos militares. As técnicas podem ser resumidas em três grupos que se destinam a: (a) atacar os receptores sensoriais (visão,

145 Batalhões de soldados marcharam e entoaram cantos bélicos à frente da Embaixada do Brasil, assim como foram instalados holofotes e alto-falantes dirigidos à Embaixada que irradiaram o hino nacional, hinos e marchas militares, música ("Rato de Duas Patas", da cantora Paquita del Barrio; "Golondrinas", de natureza fúnebre; mambos; funk caribenho (reggaeton); músicas folclóricas; e uma variedade de recursos sonoros como uivos, relinchos, cacarejos, latidos, miados, uivos de burros, sinos, sirenes, cornetas e vidro). Cf.: DÁVILA, Sérgio. Na OEA, Brasil acusa golpistas de tortura. Ocupantes da embaixada brasileira em Honduras estão sofrendo "assédio desumano e irracional" reporta diplomata. Conselho Permanente da entidade divulga texto de repúdio aos fatos relatados por embaixador brasileiro e que pede fim do "assédio"; e, MAISONNAVE, Fabiano. Noite passada teve 20 minutos sem alto-falante. Folha de São Paulo. Mundo 1. 22 de outubro de 2009, p. A17.

CUSICK, Suzanne G. Music as Torture / Music as Weapon e La Musica como Tortura / La Musica como Arma. Revista Transcultural de Música. N. 10. Dezembro/2006. Disponível em: <www.sibetrans.com/trans/ trans10/cusick_eng.htm> e <www.sibetrans.com/trans/trans10/cusick_ cas.htm>. Acesso em: 06/4/2007 e 27/05/2007; e CUSICK, Suzanne G.. "You are in a place that is out of the world...": Music in the Detention Camps of the "Global War on Terror". Journal of the Society for American Music (2008), v. 2, n. 1, p. 1-26. Disponível em: <www.journals.cambridge.org/production/action/cjoGetFulltext?fulltextid=1674936->. Acesso em: 03/03/2008. 
audição, temperatura e percepção temporal), (b) causar sofrimento autoinfligido (como posições de estresse), e (c) atingir a sensitividade cultural (envolvendo questões de gênero e identidade sexual), bem como medos e fobias individuais. Estas últimas teriam sido acrescentadas neste século ${ }^{147}$.

Cusick participou como "Fellow" de um "workshop" sobre "Reverberações Culturais da Guerra Moderna" em 2006-2007, no Centro de Estudos em História Americana da Universidade de Harvard e pesquisou certas práticas utilizadas por militares norte-americanos no Iraque, Afeganistão e Guantánamo. Concluiu que o uso de música e outras sonoridades durante interrogatórios faria parte de um conjunto de técnicas militares eufemisticamente designadas 'futilidades ${ }^{148}$, dentre as quais, Cusick cita 'música em alto volume' e 'coerção sexual' que teriam por fim persuadir o detento que sua resistência é fútil. Afirma que a música teve por propósito atormentar, disciplinar, privar de sono ou 'quebrar' detentos nos recentes conflitos, mas que tais procedimentos vêm sendo aplicados nos últimos 50 anos e não constituem novidade. Aponta que em diversas circunstâncias, a música surge combinada ou alternada com alusões de cunho religioso, cultural e de gênero (e.g. pela temática musical, "performance" do intérprete, momento ou contexto), caracterizando, por vezes, humilhação sexual, e faz a seguinte reflexão ${ }^{149}$ :

"Mas o que, de fato, música e relações de gênero têm em comum? Ambos são 'sites' de experiência sensorial (som

${ }^{147}$ PROFESSOR McCoy Exposes the History of CIA Interrogation, From the Cold War to the War on Terror. Democracy Now. 17 de fevereiro de 2006. Entrevista com Amy Goodman. Disponível em: <http://www.democracynow.org/2006/2/17/professor_mccoy_exposes_the_history_of $>$. Acesso em 12/12/2009.

148 ROSS, Alex. Futility Music. The New Yorker. 29 de maio de 2008. Disponível em: <www.newyorker.com/online/blogs/goingson/2008/05/futilitymusic.html?printable=t...>. Acesso em: 24/03/2009.

149 CUSICK, Suzanne G.. "You are in a place that is out of the world...": Music in the Detention Camps of the "Global War on Terror". Journal of the Society for American Music (2008), v. 2, n. 1, p. 1-4, 10-9. Disponível em: <www.journals.cambridge.org/production/action/cjoGetFulltext?full textid=1674936->. Acesso em: 03/03/2008. 
e sexo), pois estes são construídos por crenças culturais, e ambos são, por esta razão, meios de prática cultural através dos quais tais crenças se materializam como éticas. $\mathrm{Na}$ sociedade Ocidental, estão entre as principais formas pelas quais nos relacionamos uns aos outros como seres que são tanto sensoriais quanto 'enculturados'. Portanto, a música e 'coerção de gênero' podem agir sobre seres humanos de maneiras mais complicadas do que posições de 'stress', privação de sono, e extremos de calor ou frio que são conhecidos procedimentos na experiência de interrogatórios. Enquanto que posições de 'stress' e técnicas semelhantes visam fazer com que as vulnerabilidades do próprio corpo humano o traiam e causem dor, tanto a 'música fútil' ['futility music'] quanto a 'coerção de gênero' miram as práticas através das quais as crenças culturais se incorporam, se expressam e se materializam como práticas éticas. 'Música fútil' $e$ 'coerção de gênero' podem forçar seres humanos [...] a se autoinfligirem dor psíquica ao invés de dor física [...]. Resultando diretamente de quem são ou escolheram ser como seres humanos 'enculturados' - isto é, pessoas, e não apenas organismos biológicos sensoriais - esta dor psíquica ataca seu alvo e causa autotraição no espaço intrasubjetivo que muitas tradições religiosas chamam de alma. Quando alma e corpo entram em colapso conjuntamente na catástrofe da autotraição a resistência não é só fútil, mas impossível" (Cusick, 2008, p. 17, grifo nosso).

Em um artigo publicado em 2008, Suzanne G. Cusick chega mesmo a questionar se o recente uso de música nos centros de detenção norte-americanos funcionou como música propriamente dita ou como mero som dirigido aos prisioneiros para atacar o sentido auditivo, bombardear o corpo (pele, nervos e ossos) com energia acústica e mascarar ou prejudicar o pensamento, o senso de temporalidade e a prática religiosa (tanto da reza quanto da abstinência de atividades musicais consideradas pecaminosas). Com base nos casos analisados constatou, porém, o uso da música com o fim de manipular afetos, um dos efeitos da música. Reconhece que um dos mais horripilantes aspectos de tais procedimentos nos conflitos militares contemporâneos é a degradação do que no Ocidente se reconhece como música. Esse 
meio de expressão da criatividade, inteligência e de emoções passa a ser utilizado inclusive para interferir na privacidade, transformando-se no que designa de um 'veículo para o mal'150.

Jonathan Pieslak, professor de música do City College and Graduate Center (CUNY), em Nova Iorque, entrevistou soldados norte-americanos e concluiu que, de modo geral, a música parece ter tido um papel mais significativo na vida de soldados norte-americanos durante a Guerra do Iraque do que em qualquer conflito anterior em que os Estados Unidos esteve envolvido. Concluiu, ademais, que entre soldados norte-americanos no Iraque, os gêneros 'rock/metal' e 'rap' são os prediletos no preparo psicológico para o combate. A música do gênero 'metal', por sua vez, é a preferida nos interrogatórios e teria por efeito tanto instilar confiança e motivar quanto irritar, frustrar e destruir psicologicamente (embora o 'rap', 'pop' e músicas infantis também tenham sido utilizados). Pieslak identifica algumas características que justificariam, inclusive, a pouca variedade das músicas utilizadas ${ }^{151}$ : o alto-volume; as ofensas culturais; o timbre (as

${ }^{150}$ CUSICK, Suzanne G. Musicology, Torture, Repair. Radical Musicology, v. 3 (2008), pars. 3 e 4. Disponível em: <www.radical-musicology.org.uk/2008/ Cusick.htm>. Acesso em: 17/09/2009

${ }^{151}$ Através do 'National Security Archive' (Instituto de Pesquisa Não Governamental situado na 'The George Washington University') e com base no 'Freedom of Information Act' ('FOIA') músicos norte-americanos e de outros países entraram com pedido em outubro de 2009 solicitando divulgação de documentos envolvendo uso de música nos centros de detenção no Iraque, Afeganistão e Guantánamo. São citadas expressamente as seguintes 35 bandas e canções: AC/DC; Aerosmith; Barney theme song (Por Bob Singleton); The Bee Gees; Britney Spears; Bruce Springsteen; Christina Aguilera; David Gray; Deicide; Don McClean; Dope; Dr. Dre; Drowning Pool; Eminen; Hed P.E.; James Taylor; Limp Bizkit; Marilyn Manson; Matchbox Twenty; Meatloaf; Meow mix jingle; Metallica; Neil Diamond; Nine Inch Nails; Pink; Prince; Queen; Rage against the Machine; Red Hot Chili Peppers; Redman; Saliva; Sesame Street theme music (Por Christopher Cerf); Stanley Brothers; The Star Spangled Banner; Tupac Shakur. Vide: Musicians Seek Secret U.S. Documents on Music-Related Human Rights Abuses at Guantanamo. The National Security Archive. 22 de Outubro de 2009. Disponível em: <http://www.gwu. edu/ nsarchiv/news/20091022/index.htm>. Acesso em: 13/04/2010. 
distorções do som da guitarra com a produção de múltiplos harmônicos de alta frequência); o uso de dissonâncias (inclusive do trítono); os vocais (muitos gritos e sons guturais); o ritmo acelerado que mimetiza os sons da guerra; e, por fim, o reforço das letras, que em muitos casos revelam fascinação com o conflito, a violência, a sobrevivência e a morte. Pieslak ressalta o poder transformador da música em certas pessoas, sua qualidade de produzir alterações que permitem a convivência com a realidade da guerra, de estimular a agressividade e até de suprimir o elemento humanizador da identidade humana ${ }^{152}$.

Johnson e Cloonan concluem que ${ }^{153}$ nos recentes conflitos militares o uso da música popular norte-americana faz parte do esforço de afirmar hegemonia cultural em um momento em que as forças militares mostram todo o seu poderio e na interpretação de Suzanne G. Cusick: "A música, então, não é apenas um componente da 'tortura sem toque', mas também um componente da reivindicação simbólica norte-americana à soberania global" (Cusick, 2006, apud Johnson; Cloonan, 2008, p. 158).

Samuel Araujo, professor da Escola de Música da Universidade Federal do Rio de Janeiro (UFRJ), apresenta algumas considerações sobre esse tema como resultado de uma pesquisa envolvendo música realizada na Maré, no Rio de Janeiro. Reconhece a estranheza de se associar música com violência, tendo em vista um certo consenso universal acerca do seu valor positivo ${ }^{154}$. Porém, afirma:

"Uma outra compreensão do lugar da música ou seus correlatos em contextos diversos deveria, em nosso entendimento, não só reconhecer o papel da música e, de modo mais genérico, da comunicação sonora não verbal em processos

152 PIESLAK, Jonathan R. Sound Targets. American Soldiers and Music in the Iraq War. Bloomington: Indiana University Press, 2009, p. 3-9, 50-6, 79-85, 136-9, 150-164, 168-173.

153 JOHNSON, Bruce; CLOONAN, Martin. Dark Side of the Tune: Popular Music and Violence. Hampshire: Ashgate Publishing, 2008, p. 158.

154 ARAUJO, Samuel et alli. A violência como conceito na pesquisa musical; reflexões sobre uma experiência dialógica na Maré, Rio de Janeiro. Revista Transcultural de Música. No. 10, 2006. Disponível em: <www.sibetrans.com/trans/trans10/araujo.htm>. Acesso em: 02/10/2009. 
sociais demarcados como violentos, mas também situar reciprocamente formas de violência socialmente exercida em processos musicais ou em que a música desempenhe um papel-chave" (Araujo, 2006, grifo nosso).

Samuel Araujo constata que a violência faz parte da história do Brasil. Reporta-se aos processos recentes de violência urbana, como no caso do Estado do Rio de Janeiro, onde estão presentes estados de caráter criminoso dentro do próprio Estado e a violência, no mais das vezes, está associada ao tráfico de drogas e à atividade policial:

"Em retrospecto, a violência, tanto em sua dimensão física quanto simbólica, tem moldado vários aspectos da história sócio-política brasileira por muito tempo. Entre estes, poderíamos lembrar rebeliões e repressão em inúmeras formas: confrontos bélicos no período colonial, insurreições da população negra escravizada, discriminação racial, hierarquias culturais ativas, conflitos de terra, tortura brutal de prisioneiros políticos, mortes por crime violento, obstáculos socioeconômicos insuperáveis e assim por diante" (Araujo, 2006, grifo nosso).

Araujo fornece também exemplos da cultura da violência fomentada pelo próprio Estado, lembrando de músicas com conteúdo vilipendioso e aquelas conhecidas como 'proibidão' 155 imputadas às

155 "PROIBIDÃO é um termo que se refere a canções de apologia ao tráfico no estilo funk produzido em comunidades populares do Rio de Janeiro, encontrados em CDs de confecção doméstica vendidos ilegalmente em toda a cidade. Sua aplicação à produção de funks com conteúdo de ameaça a moradores das favelas atribuida a integrantes da tropa de elite da policia é relativamente recente." (Araujo, 2006); e, "Proibidão é um estilo de funk comercializado de forma clandestina cujas canções fazem apologia ao tráfico e à violência contra a polícia (nota da Redação)". In: VIANNA, Hermano. Raiz da Questão. Entregamos o ouro ao bandido. Raiz. Cultura do Brasil. Edição n. 01. Revista Raiz. Disponível em: <http://revistaraiz.uol.com.br/portal/ index.php?option=com_content\&task=view\&id=33\&Itemid=48>. Acesso em: 26/03/2010. 
PMs e ao BOPE, bem como as operações com os blindados denominados 'caveirão':

"Hoje, na internet, também se encontra facilmente em comunidades policiais músicas do gênero 'proibidão', atribuídas a PMs. Alguns exemplos de textos de música são significativos: 'Bope vai te pegar, Bope vai te pegar, homem de preto, qual é tua missão? Entrar pela favela e deixar corpo no chão'. Outra fala do carro blindado denunciado: 'O terror deste Rio é o Caveirão, entra em favela, invade o morrão. Se você canta e tem amor à vida, vamos meter bala e não é perdida'.

Esses são exemplos da cultura de violência presente também no próprio Estado" (Araujo, 2006, grifo nosso).

Neste tocante, mesmo no Brasil encontramos registros de violência sonora. Detidos durante o Regime Militar foram confinados em câmaras de ruídos instaladas no Rio de Janeiro ${ }^{156}$, assim como o rádio em alto volume serviu de trilha sonora aos interrogatórios e à tortu$\mathrm{ra}^{157}$. Militares também submeteram seus prisioneiros a outros expedientes degradantes com música que inevitavelmente nos remetem a fatos semelhantes ocorridos nos campos de concentração nazistas descritos anteriormente.

Durante a Guerrilha do Araguaia, por determinação dos militares, moradores locais presos, em sua maioria homens idosos, eram reunidos e obrigados a cantar a canção conhecida por "pula-pula", bem como realizar diversos movimentos como pular, sentar, levantar, cair, entre pontapés e sopapos ${ }^{158}$ :

${ }^{156}$ GASPARI, Elio. A Ditadura Escancarada. São Paulo: Companhia das Letras. 2007, p. 189-190. ARQUIDIOCESE DE SÃO PAULO. Brasil Nunca Mais. 35ª ed. (1985). RJ, Petrópolis: Editora Vozes, 2007, p. 37-8.

157 JOFFILY, Mariana. No Centro da Engrenagem. Os interrogatórios na Operação Bandeirante e no DOI de São Paulo (1969-1975), São Paulo, 2008, 351f. Tese de Doutorado. História Social. Departamento de História, da Faculdade de Filosofia, Letras e Ciências Humanas da Universidade de São Paulo, p. 301.

158 GASPARI, Elio. A Ditadura Escancarada. São Paulo: Companhia das Letras, 2007, p. 438; e, MORAIS, Tais. Sem Vestígios. Revelações de um 
"É um tal de pula-pula, é um tal de soca-soca; quem tem culpa se enrola, quem não tem logo se apura. Quem apoia, não apoia, não importa pro doutor; quem disser que não apoia quando sabe que apoiou, dá um traço nos meninos, que é pior que terecô" (Morais, 2008, p. 122).

Outro acontecimento envolvendo 'música sob coerção' é descrito pelo jornalista, crítico musical e escritor Carlos Calado, que inicia sua obra "Tropicália - A História de uma Revolução Musical" com um capítulo designado "Cantando Atrás das Grades". E, logo nas primeiras páginas do livro, descreve duas apresentações musicais feitas por Caetano Veloso e Gilberto Gil enquanto prisioneiros do regime militar. Os dois haviam sido detidos por oficiais do Exército em São Paulo, em 27 de dezembro de 1968, e transferidos para o Rio de Janeiro ${ }^{159}$ :

"Gilberto Gil jamais tinha feito um show tão estranho. Naquela noite quente de verão, em fevereiro de 1969, cantou e tocou violão para cerca de 150 soldados e oficiais do Regimento de Paraquedistas, num quartel da Vila Militar de Deodoro, no Rio de Janeiro. O espetáculo não teria nada de tão excepcional se Gil não fosse um prisioneiro. Estava detido ali havia três semanas, de forma arbitrária, depois de passar outro tanto trancafiado em dois quartéis da Polícia do Exército. [...] Separado do amigo e parceiro, preso em outro quartel da mesma Vila Militar, Caetano Veloso teve menos sorte. Não só viu recusado seu pedido de um violão, como se viu intimado a fazer um recital mais insólito ainda que o de Gil" (Calado, 1997, p. 9-10, grifo nosso).

Caetano Veloso dá os detalhes da apresentação em sua autobiografia "Verdade Tropical". Recorda que um soldado durante um banho de sol solicitou que cantasse o samba-canção "Fracasso", su-

agente secreto da ditadura militar brasileira. São Paulo: Geração Editorial, 2008, p. 122.

159 CALADO, Carlos. Tropicália. A História de uma Revolução Musical. São Paulo: Ed. 34, 1997, p. 9-10. 
cesso de Francisco Alves (1898-1952) e composição de Mário Lago $(1911-2002)^{160}$ :

"O samba, com sua melodia triste em tom menor, me agradava, e, à medida que o ia cantando, tal como ocorreu com 'Súplica' na Barão de Mesquita, eu ia interpretando as palavras da letra como referentes à minha situação. Hoje vejo com um misto de humor e nojo aquela cena no grande espaço aberto do quartel do PQD. Sob um sol brutal, com um cano de metralhadora às costas, eu cantava suavemente para o oficial de dia: '... Porque só me ficou da história triste desse amor / A história dolorosa de um fracasso'... A palavra 'fracasso' é ouvida sete vezes ao longo da letra, culminando com a repetição insistente nas notas mais altas no final da canção: 'Fracasso, fracasso, fracasso, fracasso afinal / Por te querer tanto bem / E me fazer tanto mal'. Tal palavra - repetida por mim em tais condições, e ainda por cima vulnerabilizado como eu ficava pela beleza da música e a carga de emoções que ela despertava por seu valor histórico tornava-se uma conjuração maligna em minha imaginação. E às vezes, sozinho na cela, fazia esforço para afastar essa canção de minha cabeça, na qual ela sempre recomeçava a se cantar por si mesma." ... 'Fracasso' representava uma senha para o inferno. Contudo, estou certo de, depois disso, ter tido que cantá-la pelo menos mais uma vez para aquele tenente" (Veloso, 2008, p. 382-383, grifo nosso).

E, por fim, fica a lembrança do médico Aytan Miranda Sipahi, detido no Presídio Tiradentes, em São Paulo, durante o Regime Militar:

"Vale acrescentar o toque de irônica brasilidade que descia todos os dias rigorosamente às 21h: o sistema de som do presídio tocava "Tico-tico no fubá" para indicar a hora do silêncio" (Freire; Almada; Ponce, 1997, p. 235, grifo nosso) ${ }^{161}$.

160 VELOSO, Caetano. Verdade Tropical. São Paulo: Companhia das Letras, 2008, p. 382-3.

161 FREIRE, Alípio; ALMADA, Izaías; PONCE, J.A. de Granville (Orgs.). Tiradentes, um Presídio da Ditadura. Memórias de Presos Políticos. $1^{\mathrm{a}} \mathrm{ed}$. São Paulo: Scipione Cultural, 1997, p. 235. 
O choro 'Tico-Tico no Fubá', composição de José Gomes de Abreu, conhecido como Zequinha de Abreu (1880-1935), e letra de Eurico Barreiros, alcançou o auge de sua popularidade na década de 1940 na voz de Carmen Miranda (1909-1955). Vale a pena transcrever parte de sua tão popular letra:

'Tico-Tico no Fubá162:

\section{"Um tico-tico só. O tico-tico lá}

Está comendo todo, todo, meu fubá

Olha, seu Nicolau. Que o fubá se vai

Pego no meu Pica-pau e um tiro sai..."

Johnson e Cloonan observam que as reações negativas causadas por uma canção em volume abaixo do limiar da dor têm origem na violação de um espaço privado (aspecto este também ressaltado por Cusick, considerando, inclusive, a atual experiência musical gerada pelos aparelhos portáteis ${ }^{163}$ ), mas podem derivar também de outras objeções de cunho estético e moral. Quanto às canções com conteúdo vilipendioso, para certos especialistas, por si já constituiriam um ato de violência social ou 'simbólica'. Sugerem que à indagação de que se canções dessa natureza causam violência se acrescente a expressão - outros atos de violência. Não obstante, alertam que músicas que incitam violência não necessariamente trazem uma mensagem explícita nesse sentido e lembram a importância de outros componentes como o volume, a instrumentação, a melodia, a harmonia e, não menos importante, o contexto em que são ouvidas ${ }^{164}$.

Além dos trágicos episódios envolvendo música nos campos de concentração nazistas, os professores relembram outros fatos, como

162 ZEQUINHA DE ABREU. Biografias. UOL Educação. Disponível em: $<$ http://educacao.uol.com.br/biografias/ult1789u182.jhtm?action=print $>$. Acesso em: 05/02/2010.

${ }^{163}$ CUSICK, Suzanne G. Musicology, Torture, Repair. Radical Musicology, v. 3 (2008), pars. 7-10. Disponível em: <www.radical-musicology.org. uk/2008/Cusick.htm>. Acesso em: 17/09/2009.

164 JOHNSON, Bruce; CLOONAN, Martin. Dark Side of the Tune: Popular Music and Violence. Hampshire: Ashgate Publishing, 2008, p. 62, 73, 121-2, 139-145. 
a imposição aos infratores de cantar o hino nacional em casos de violação de regras de tráfego nas Filipinas e aos prisioneiros Croatas, obrigados a cantar o Hino Nacional Iugoslavo por determinação das forças Sérvias (conforme também reporta Pieslak ${ }^{165}$ ) e, de modo geral, a obrigação dos cativos de cantar músicas patrióticas dos inimigos ou opositores. A imposição de música geralmente constitui ato de violência, e a ausência de controle sobre as próprias manifestações sonoras constitui profunda e dolorosa violação da integridade. Forçar alguém a cantar ou a tocar pode parecer trivial, mas, dependendo das circunstâncias, pode ser parte de um contexto mais brutal de humilhação ${ }^{166}$.

A questão do contexto também é enfatizada por Alexandre Felipe Fiúza em sua Dissertação de Mestrado ${ }^{167}$. Observa que, embora não seja possível afirmar que a música desperta emoções e sentimentos uniformes em toda a parte, na medida em que se apresenta em um contexto ou situação, gera uma representação, "passa a trazer uma série de significados implícitos" (Fiúza, 2001, p. 55). Um exemplo bastante contundente é a música de Richard Wagner que, após sua morte, foi apropriada e reinterpretada por Adolf Hitler e ainda hoje é associada por muitos às atrocidades nazistas. Conforme aponta o professor Contier ${ }^{168}$ :

"Para compreender a estetização da política e da propaganda como o ponto nodal do imaginário nazista, torna-se imprescindível analisar a reinterpretação da obra de Richard Wagner realizada por Adolf Hitler, numa conjuntura específica:

${ }_{165}$ PIESLAK, Jonathan R. Sound Targets. American Soldiers and Music in the Iraq War. Bloomington: Indiana University Press, 2009, p. 86.

166 JOHNSON, Bruce; CLOONAN, Martin. Dark Side of the Tune: popular music and violence. Hampshire: Ashgate Publishing, 2008, p. 154-8.

${ }^{167}$ FIUZA, Alexandre Felipe. Entre cantos e chibatas: a pobreza em rima rica nas canções de João Bosco e Aldir Blanc, Campinas, 2001, $271 \mathrm{f}$. Dissertação (Mestrado) - Universidade Estadual de Campinas. Faculdade de Educação, p. 55.

${ }^{168}$ CONTIER, Arnaldo Daraya. Tragédia, Festa, Guerra: os coreógrafos da modernidade conservadora. In: Revista USP / Dossiê 50 anos de Final de Segunda Guerra. Coordenadoria de Comunicação Social, Universidade de São Paulo, n. 26, junho/agosto 1995. São Paulo: USP, CCS, p. 20-41. 
os anos 20 e 30. Conforme Richard Wagner, a construção de uma utopia revolucionária da arte somente poderia ser elaborada tendo como ponto de partida uma determinada reinterpretação da cultura e da tragédia gregas.

[...]

A partir dessa concepção wagneriana, Hitler 'interpretou' a natureza biológica e cultural do homem 'nórdico ou ariano' como símbolo da 'coragem' e da sua natural vocação militar, capaz de desencadear uma 'guerra' permanente contra todos os 'inimigos' internos e externos da nação...” (Contier, 1995, p. 34, grifo nosso).

O músico e maestro argentino naturalizado israelense, Daniel Barenboim, tocou Wagner em Israel em 2001, o que gerou críticas e enorme celeuma. Barenboim relata a seguinte indagação de uma senhora indignada ${ }^{169}$ :

"Como você pode tocar isso? Eu vi a minha família sendo levada para as câmaras de gás ao som da abertura de 'Meistersinger'170. Por que eu tenho de escutar isso? Resposta simples: ela não tem por que escutar isso. Não acho que se deva impingir Wagner a ninguém,..." (Barenboim, In: Barenboim; Said, 2003, p. 113, grifo nosso).

Por sua vez, Edward W. Said, crítico literário, defensor da causa palestina e grande amigo de Barenboim, faz as seguintes considerações ${ }^{171}$ :

"A música de Richard Wagner sempre foi informalmente proibida em Israel, apesar de às vezes ser tocada na rádio e de estar disponível nas lojas de discos. Para muitos judeus

169 BARENBOIM, Daniel; SAID, Edward W.. Paralelos e Paradoxos. Reflexões sobre Música e Sociedade. São Paulo: Companhia das Letras, 2003, p. 113.

${ }^{170}$ Die Meistersinger Von Nurburg ("Os Mestres Cantores de Nuremberg"): ópera de Richard Wagner.

171 SAID, Edward W. Barenboim e o Tabu Wagner. In: BARENBOIM, Daniel; SAID, Edward W. Paralelos e Paradoxos. Reflexões sobre Música e Sociedade. São Paulo: Companhia das Letras, 2003, p. 177-188. 
israelenses, a música de Wagner - rica, extraordinariamente complexa, extraordinariamente influente no mundo musical - simboliza os horrores do antissemitismo alemão. Entretanto, Wagner foi, incontestavelmente, um grande gênio do teatro e da música. Ele revolucionou toda a nossa concepção de ópera; transformou por completo o sistema tonal e deixou dez grandes obras primas, dez óperas que se situam no patamar mais alto da música ocidental. $O$ desafio que Wagner apresenta, não só para judeus israelenses, mas para todo o mundo, é: como admirar e executar sua música, por um lado, e, por outro, como separá-la de seus textos odiosos e do uso que os nazistas fizeram deles" (Said, In: Said, Barenboim, 2003, p. 177, grifo nosso). 
